\title{
LoCal InStitutions, Poverty AND HOUSEHOLd WELFARE IN BOLIVIA
}

\section{Christiaan Grootaert}

Deepa Narayan

July 2001

The World Bank

Social Development Family

Environmentally and Socially

Sustainable Development Network 



\section{TABLE OF CONTENTS}

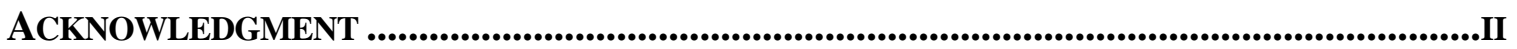

1. INTRODUCTION: LOCAL INSTITUTIONS AND SOCIAL CAPITAL ......................................3

2. Poverty, ETHNiCITY AND GovernanCE IN BOLIVIA ..................................................5

3. THE LOCAL LEVEL INSTITUTIONS STUDY AND THE DATA SET ....................................8

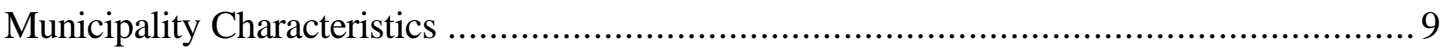

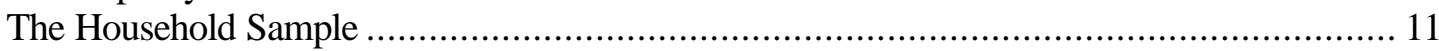

4. THE MAP OF LOCAL INSTITUTIONS ......................................................................16

5. COMPLEMENTARITY AND SUBSTITUTION B ETWEEN ORGANIZATIONS ........................25

6. THE M EaSUREMENT OF SOCIAL CAPITAL..............................................................28

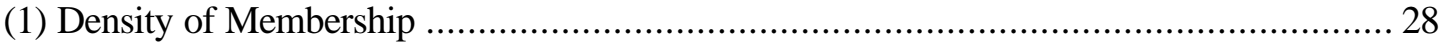

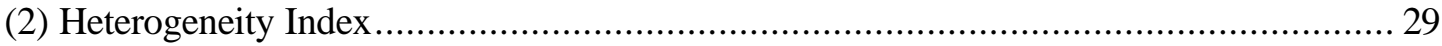

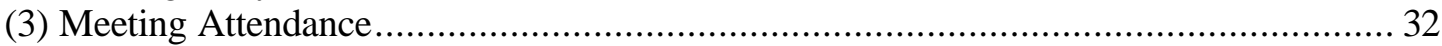

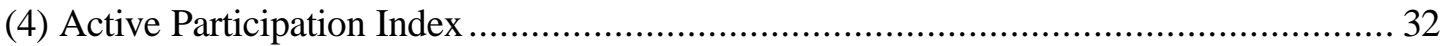

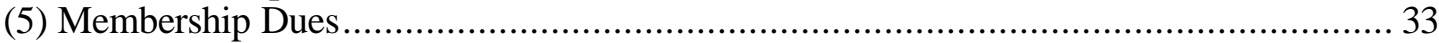

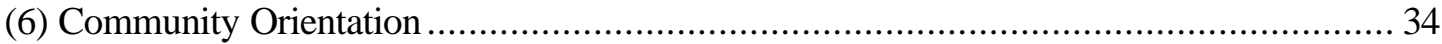

7. Household Welfare and Social CaPital........................................................35

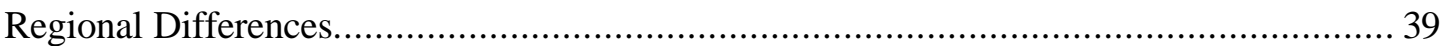

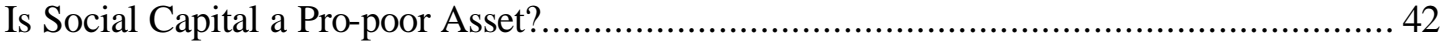

8. The Effects of Social Capital: Asset Accumulation, Access to Credit, COMMUNITY ASSISTANCE, AND COLLECTIVE ACTION.......................................................47

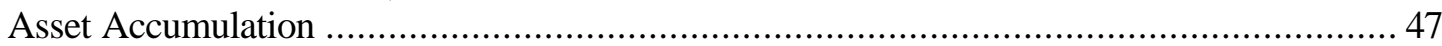

Access to Credit and Community Assistance................................................................. 48

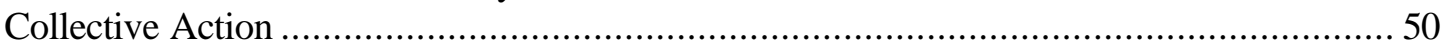

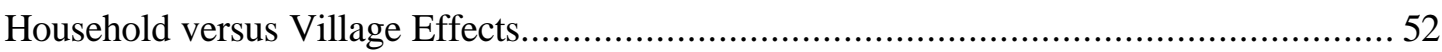

9. Social Capital and Household Welfare: Two-Way Causality? .................54

10. SUMMARY AND CONCLUSION ....................................................................................57

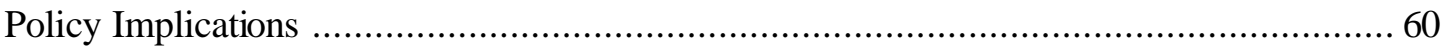

ANNEX: MEANS AND STANDARD DEVIATION OF R EGRESSION VARIABLES .....................62

REFERENCES .................................................................................................................................63 


\section{ACKNOWLEDGMENT}

The authors would like to thank Anthony Bebbington for helpful comments on an earlier draft. The processing and management of the data files was the responsibility of Kalpana Mehra and Gi-Taik Oh. General research assistance was provided by Susan Assaf and Ben Jones. Gracie Ochieng was responsible for text processing.

The Local Level Institutions (LLI) study was conducted under the leadership of Gloria Davis, Director, Social Development Department. In the initial phases, task Managers were Anthony Bebbington (July 1995 - June 1996) and Christiaan Grootaert (July 1996 - December 1997). The final phase of the study was undertaken as a joint venture between the ESSD and PREM Networks and co-managed by Christiaan Grootaert and Deepa Narayan. The study received financial support from the Government of Norway.

The Bolivia country-study was undertaken by a team from the consulting firm Sinergia. Coordinator was Godofredo Sandóval and the research team consisted of Julio Cordova, Beatriz Ascarrunz, Afredo Balbóa, Griselda Gonzales, and Gloria Velasquez.

The Burkina Faso country-study was coordinated by Paula Donnelly-Roark. The field work was undertaken under the auspices of the Commission Nationale pour la Décentralisation.

The Indonesia country-study was coordinated by Scott Guggenheim and the research team consisted of Kamala Chandrakirana, Pieter Evers, Sjari Manaf and Silvia Werner. 


\title{
1. INTROdUCTION: LOCAL INSTITUTIONS AND SOCIAL CAPITAL
}

\author{
Of every four Bolivians, three are Indians
}

Xavier Albó, 1994

With decentralization the current rage in development, the importance of local level institutions should reach new heights. Yet, the primary focus in the decentralization literature is on the structures and functions of devolved formal authorities. Formal government systems are embedded in the local social organizational context. Hence understanding how and when local governments become inclusive and function effectively in basic service provision and poverty reduction, requires understanding the interplay between the formal and informal institutions and the interplay between history, politics and changes in social organization over time. This requires overlaying quantitative data with historical qualitative data. The Local Level Institutions (LLI) Study in Bolivia, provides a particularly rich context to disentangle these relationships.

We combine two rich data sets both of which were collected as part of the LLI Study. The qualitative data explore the history, politics and dynamics of local associations, municipal government, and the history and nature of social relations in four different municipalities: Mizque, Charagua, Tiahuanacu and Villa Serrano. We use a quantitative data set derived from a household survey to develop indices of social capital and econometric techniques to explore linkages between poverty and social capital at the household and community level in the same four municipalities. Both data sets were created by the Sinergia group in Bolivia led by Godofredo Sandoval. We also make extensive use of their report Grassroots Organizations and Local Development in Bolivia written by Sandoval and associates (1998).

We draw four main conclusions. First, social capital measured by memberships in agrarian syndicates and other associations matters for poverty reduction. Some dimensions of social capital or characteristics of groups are more central than others. Household and village social capital matters but so does bridging or linking social capital. As an asset, social capital matters more for the poor than the non-poor and has greater effect on household welfare than investment in primary education. Households with higher social capital are likely to have more permanent physical assets which help them smooth consumption during periods of income fluctuation. They are more likely to participate in collective action and be able to draw on community resources in times of need.

Second, there is a relation of complementarity and substitution between the informal and formal institutions. At the municipal level, the relationship between social capital and welfare is modified by the nature and presence of other formal institutions. Thus, Mizque achieves complementarity between strong traditional institutions, strong supra-community linkage organizations, and effective municipal government. Mizque is also the most prosperous of the four municipalities. On the other extreme is Villa Serrano, 
in which the traditional institutions are weak and exclude the poor, the poor belong to other local associations to cope with poverty, and there are weak linkage organizations and an ineffective municipal government. Villa Serrano is the poorest of the four municipalities. Charagua, which has managed a renewal of supra-community indigenous organizations, has an effective municipal government even though it is dominated by the elite, and experiences higher levels of economic prosperity.

Third, history, politics and the existing social and power structures have farreaching effects on social capital formation. However, when there are deep changes in law, politics, economic structure and markets, changes in social capital formation which lead to poverty reduction are possible. The strategy has to be context specific. Over the long run NGOs and other external agents can play a critical role in bringing about positive changes in poverty-reducing social capital. The form of assistance is context-specific and needs to be derived from a thorough diagnosis of the local social, political, institutional and economic context situated in the broader national context.

Fourth, the degree of access to markets and ease of communication through proximity to major roads and access to electricity affects both economic opportunities and social capital formation. When economic opportunities are low in the local areas, people migrate to cities seeking new sources of income. This affects organizational life. However, proximity to cities, such as in Tiahuanacu, results in migrants maintaining close contact with the local areas. Organizational life seems to be most regatively affected in areas of low economic potential, with migration into cities and physical isolation. This is most evident in Villa Serrano. However, as new opportunities open up in local areas, communities witness reverse migration, as many indigenous groups prefer to live in their own communities where their tradition, identity and culture are honored. This is clearest in Charagua. 


\section{Poverty, EThNicity ANd GovernanCe in Bolivia}

Bolivia, with a population of 7.2 million, is a poor country with great ethnic and geographic diversity. Based on an index of unsatisfied basic needs ${ }^{1}$ set in 1992 , approximately $70 \%$ of the population was classified poor. Overall, $94 \%$ of the rural population was classified poor, compared to $98 \%$ in 1976 . In addition, among the poor, about $90 \%$ were classified as being below the extreme poverty line. In terms of urban poverty, while $50 \%$ of the population was classified poor in 1992 , the number was $65 \%$ in 1976 (World Bank, 1996).

Radical structural adjustment measures in the 1980's consisting of liberalization of most prices, privatization, reform of public enterprises and closing of unprofitable mines, helped curtail hyper-inflation. It also led to increased migration to the cities $(30,000$ miners were laid off) and did little for poverty reduction in the rural areas.

Seventy percent of the population is indigenous. There is great overlap between being poor and being indigenous. In rural areas, $90 \%$ of the population is indigenous, primarily Aymara and Quechua, who traditionally live in the altiplano and the valley of the high Andes. Poverty and extreme poverty are more prevalent in Aymara speaking households. Another 30 to 40 ethnic and language groups are spread across the altiplano and lowlands of Eastern and Northern Bolivia (Ströbele-Gregor, 1994, Albó, 1994).

According to World Bank (1996) estimates, 1) being indigenous increases the probability of being poor by about $14 \%$; 2 ) each additional child increases the probability of being poor by $6.5 \%$; 3) an unemployed household head increases the probability of being poor by about 14\%; and 4) each additional year of schooling reduced the probability of being poor significantly. In all studies, indigenous women appear the worst off on every measure of basic needs.

Bolivia has an unequal distribution of income, which is severe even by Latin American standards. This inequality has not improved over time (Birdsall et al. 1998). In a cross-country analysis, Birdsall and Londoño (1997) have shown that the greater the initial inequality in land and education, the lower the growth rates experienced by countries. The impact of initial inequality on income growth more than doubles when the sample is restricted only to poor countries.

Most writers on Bolivia agree that Bolivian society since 1532 has been a highly stratified dual society of Spaniards and Indians. Following independence in 1825, the Bolivian state was dominated by a small oligarchy of tin-mining interests until the defeat in the Chaco War against Paraguay in the 1930s (Albó, 1994; Garcia Arganaras, 1992). This defeat proved to be so traumatic that it generated widespread questioning of the

1 The implied rural poverty line was 158.9 Bs per month (59\% of the urban poverty line) and the extreme poverty line in rural areas was 119.2 Bs per person per month $(80 \%$ of the urban equivalent). 
landed and mining interests ruling both state and society. It sowed the seeds for the emergence of the MNR (Movimiento Nacionalista Revoluciónario) - a revolutionary alliance of urban traders, peasants, and mine-workers. The 1952 agrarian reform was part of this process whereby land was redistributed, mines nationalized and peasant organizations, the sindicatos, 'incorporated' into the state. The goal was a nation state with the culture of the Mestizo, with the Indians and half-Indians adopting the culture of the ruling society and becoming culturally white (Albó, 1994). The land redistribution was not equally successful everywhere and in many areas haciendas remained intact (StröbeleGregor, 1996).

It was only in the early 1980's that Bolivia moved from a military state to a democratic state. The 1980's marked the beginning of an adoption of neoliberal marketbased economic strategies and the gradual consolidation of democracy (Albro, 1998). The growing gap between ideology and a reality which denied basic rights, fostered widespread discrimination and excluded indigenous groups from all spheres of social, political and economic life, led gradually to the emergence of cultural identity movements, identity politics and demands for autonomous organizations and cultural pluralism. In the early 1970's the Katarista movement emerged among the Aymara Indians. The movement was named in memory of Tupaj Katari, an Aymara leader who led an anticolonial uprising in 1781. This movement was also the forerunner of the first independent national peasant confederation, the CSUTCB, (Confederación Única de Trabajadores Campesinos de Bolivia) established in 1979. While the Katarista movement experienced internal rifts and difficulties in organizing, the ideas they espoused, including the creation of a plurinational state, gained ground (Albó, 1995). In the late 1980's indigenous organizations emerged in the lowlands of eastern Bolivia, and in 1991 the Coordinator of Indigenous Peoples of the Beni led the well-publicized "March for Territory and Dignity" in which 12 ethnic groups marched 700 kilometers through the jungle and the snow-capped Andes to La Paz, captivating the country's attention for 40 days and creating national awareness of their issues (Albó, 1995). But while the indigenous groups created political parties, they did not do well at the polls. This was due to lack of funds, parochial organization and internal divisions. Within the Katarista movement, it was Victor Hugo Cárdenas, an Aymara and Katarista movement leader since 1978 who came to the fore. A one-time parliamentarian, Cárdenas was invited to share a presidential ticket with Gonzalo Sanchez de Lozada to form a coalition with the MNR for the 1993 election. The MNR alliance with the MRTKL (Movimiento Revolucionario Tupaj Katari de Liberación) won the election, and an Aymara Indian became a Vice-President for the first time.

Having instituted structural economic reforms in the 1980's and having won the 1993 elections, the MNR government, under the leadership of President Sanchez de Lozado, undertook a second generation of reforms to deepen economic changes and democracy and to address the issues of inequality resulting from 500 years of ethnic exclusion.

In a radical step to address rural poverty issues, Bolivia promulgated the Law of Popular Participation (Ley de Participación Popular, LPP) in 1994, and the Decentralization Law (Ley de Descentralización Administrativa, LDA) in 1995, which gave resources and responsibilities to municipalities and structured the involvement of 
local grassroots organizations in the planning, implementation and monitoring of municipal government. ${ }^{2}$ Almost overnight, Bolivia moved from a highly centralized political, administrative and economic state, to a devolved state consisting of 311 municipalities, 248 of which were newly created. Over $30 \%$ of the municipalities were small and consisted of less than 5,000 people (Tuchschneider, 1998). Whereas before the reform the three main cities received $84 \%$ of all devolved funds while the majority of rural communities received nothing, after the reform the share of the three cities fell to $29 \%$ and provincial and rural area budgets increased from $42 \%$ to over $3000 \%$ (Faguet, 1998). The criteria of allocation of resources to different areas shifted from one of political consideration to allocation based on population. Title to local infrastructure and future provision of basic services became a municipal responsibility. Most importantly, the LPP recognized over 15,000 existing territorial organizations, indigenous organizations, peasant organizations and neighborhood councils as legitimate grassroots organizations and incorporated them into 1,600 Oversight Vigilance Committees (OTBs) (Tuchschneider, 1998). To keep municipalities accountable, the Oversight Committees were to channel local citizen preferences and demands and provide independent oversight over municipal resource allocation decisions and actions. Thus, for the first time in Bolivia, OTBs became the chief local mechanism for ensuring local government accountability.

Bolivia is also characterized by great regional differences in social structure, in the degree of harmony and conflict and the nature of social relations between indigenous and Spanish populations, the degree of inclusion of indigenous groups in formal systems of governance, the degree of social cohesion among indigenous groups, the presence of 'linkage' organizations, the degree of linkage to markets and the presence of NGOs. These factors comprise the social capital of an area and influence the extent to which OTBs can function effectively to create responsive municipal governments. It is against this history of repression, exclusion, and radical economic and social restructuring that the results from our study need to be considered.

2 A third law enacted at that time relates to privatization of public enterprises, and stipulated that half the proceeds from the sales will be used to create a national pension fund and solidarity bonds for all Bolivians above age 21. The educational system will also be updated to reflect the cultural and linguistic diversity of Bolivia. 


\section{The Local Level InStitutions Study ANd The Data SeT}

The data set for this paper comes from the Local Level Institutions (LLI) Study, a comparative study for three countries (Bolivia, Burkina Faso and Indonesia), that aims to investigate the role of local institutions in providing service delivery and in affecting welfare and poverty outcomes. ${ }^{3}$ Data were collected at the community, the district and the household level.

At the level of the community, interviews with focus groups of households and with community leaders were held to establish a map of functioning institutions in the community. Three instruments were used:

- Information on community services was obtained through interviews with key informants such as the village chief, teacher, health provider, etc. This was supplemented with information on the local economy (infrastructure and distance to markets), local society (ethnic/religious composition) and local institutions.

- Community services were also discussed with groups of households, with the objective of learning the community's perspective on the quality of service, its experience with collective action, and its views on local institutions and development projects.

- For the most important local institutions, interviews were held with leaders and members, as well as non-members, in order to get a balanced view of the role of the institutions in the village, their development over time, their main activities, relations with other institutions and government, and their main strengths and weaknesses.

At the district level (defined as the administrative level above the village or community), data were collected concerning the extent of service coverage and the institutional arrangements for the provision of services. Information was also obtained about the general functioning of the district administration and its relation with civic organizations, through interviews with general and sectoral managers at the district level.

The third and critical part of the data collection was a household survey that aimed to capture households' actual participation in local institutions, their use of services, and information that identifies the welfare level of households and their coping strategies. The questionnaire consisted of six sections:

3 The objectives of the Local Level Institutions Study and the questionnaires are further discussed in World Bank (1998). 
- demographic information on household members

- participation in local institutions

- characteristics of the most important groups

- service provision profiles

- perceptions of community trust and collaboration

- household economy and coping strategies.

The limited resources available did not make possible a sampling framework such that the studies would be representative for the countries at the national level. Instead, three or four areas were selected in each country (municipalities in Bolivia, provinces in Burkina Faso and Indonesia), which represent different economic, social and institutional environments. In the case of Bolivia, the collected data covered four municipalities ("municipios"): Charagua, Mizque, Tiahuanacu and Villa Serrano.

Bolivia is a country with a strong geographical and cultural heterogeneity. Climate, ecology and altitude vary significantly, ranging from the eastern plains at about 1,000 meters above sea level, to the highlands at altitudes approaching 4,000 meters above sea level. As already discussed, Bolivia is a multi ethnic and multi-lingual country. The three most important indigenous groups are the Aymara who live in the highlands, the Quechua who inhabit the valleys, and the Guarani in the eastern lowlands. The four selected municipalities cover the main ecological zones of Bolivia as well as its principal indigenous groups.

\section{Municipality Characteristics ${ }^{4}$}

Mizque, population 20,000, is located in Bolivia's central valleys in the Cochabamba department at about 2,200 meters above sea level (Table 1). The climate is hot and the area is subject to periods of drought. It is inhabited by Quechua campesinos who farm intensively on small parcels of land. Agriculture, irrigated and unirrigated, is the most important economic activity and there are several irrigation committees to manage water resources collectively. Most land tenure has its origin in the adjudication of expropriated haciendas, but in most cases, land ownership has still not been legalized. Mizque experiences seasonal migration to Chapare where young men work as day laborers in the production and processing of coca leaf. Young women go to Cochabamba to work as domestic servants. Mizque has a trunk road that connects the municipal capital with Cochabamba, 180 kilometers away.

4 These descriptions are summarized from Sandoval et al, 1998. For full descriptions see their report. 
Table 1: Selected Socio-Economic Characteristics of the Study Areas

\begin{tabular}{|c|c|c|c|c|}
\hline & Charagua & Mizque & "Tiahuanacu & "Villa Serrano \\
\hline Region & Chaco Plain & $\begin{array}{l}\text { Central } \\
\text { Valleys }\end{array}$ & Andean & $\begin{array}{l}\text { Southern } \\
\text { Valleys }\end{array}$ \\
\hline $\begin{array}{l}\text { Altitude } \\
\text { (meters above sea level) }\end{array}$ & 980 & 2,225 & 3,870 & 2,378 \\
\hline Population & 18,769 & 20,170 & 13,151 & 12,616 \\
\hline Rural population (\%) & $71 \%$ & $96 \%$ & $92 \%$ & $80 \%$ \\
\hline $\begin{array}{l}\% \text { of communities with } \\
\text { primary school }\end{array}$ & $79 \%$ & $22 \%$ & $100 \%$ & $61 \%$ \\
\hline $\begin{array}{l}\text { Number of health centers } \\
\text { and hospitals }\end{array}$ & 16 & 11 & 6 & 7 \\
\hline
\end{tabular}

Source: Sandoval et al (1998).

Tiahuanacu, population 13,000, is located in the highlands just an hour away from the city of La Paz. An asphalt road connects it to the Bolivian capital. Tiahuanacu has the best developed road system of the four provinces with secondary roads passable throughout the year. Cold and arid, Tiahuanacu is located at an altitude of 3,900 meters above sea level. It is inhabited by Aymara campesinos who engage in subsistence farming and dairy production. Even within the municipality, which consists of 41 communities, the agro-ecological zones vary considerably in agricultural prosperity. In this area, land reform did result in the break-up of haciendas. Life in Tiahuanacu is dominated by the proximity to La Paz. Seasonal and permanent migration among the young to La Paz is a fact of life and is reflected in the fact that $41 \%$ of household heads are over 56 years of age, compared to approximately $20 \%$ in the other three municipalities.

Charagua, population 19,000, is located on the plains of Eastern Bolivia at an altitude of about 1,000 meters. It is populated by the Guarani who until recently have been dominated by the Criollo minority. It is an 8 hour trip by road from the city of Santa Cruz. Unlike the other municipalities, Charagua has experienced population growth. This is because the in-migration of merchants and the poor who come for the cotton harvest has more than offset the out-migration to Santa Cruz, Argentina, Paraguay and Brazil. The Guarani indigenous population lives side by side with hacienda owners engaged in raising livestock and the exploitation of forests. Local power is concentrated in the hands of timber companies and cattle ranchers. The municipality consists of three agro-ecological zones: the scrub forest, the foothills and the sandy Chaco plain with very low rainfall and some of the poorest communities in the municipality.

Villa Serrano, population 13,000, is located in the valleys of southern Bolivia at about 2,400 meters above sea level. It is 155 miles away from the city of Sucre. Its varied climate is typical of the many different micro-climates found in the mountainous Andean countryside. Its population, although original Quechua, has been largely hispanicized and practices subsistence farming. Haciendas still exist in this part of the country and control local power. The small population is dispersed over large areas which leads to migration and poor social service coverage. In Villa Serrano, the population has declined because of out-migration primarily to the more prosperous Santa Cruz department. 


\section{The Household Sample}

Within each municipality, nine rural communities were selected randomly. The capital of the municipality was included to represent the urban areas. In each of these sampling units, 25 households were selected randomly for a total sample of 1,000 households. ${ }^{5}$ The following tables provide a brief description of the social and economic characteristics of the sample households.

In order to evaluate whether the characteristics of the respondent, specifically gender and position in the household, would have an effect on responses, the field work was organized to attempt to interview roughly 50\% men and 50\% women. Table 2 indicates that this objective was fairly well achieved: for the study zone as a whole, 53\% of respondents were male and $47 \%$ were female. Almost two-thirds of the respondents were heads of households and one-third were spouses.

Table 2: Selected Characteristics of Respondents (in \%)

\begin{tabular}{|c|c|c|c|c|c|}
\hline & Charagua & Mizque & Tiahuanacu & $\begin{array}{c}\text { Villa } \\
\text { Serrano } \\
\end{array}$ & All \\
\hline $\begin{array}{l}\text { Gender of Respondent } \\
\text { Male } \\
\text { Female }\end{array}$ & $\begin{array}{l}48.8 \\
51.2\end{array}$ & $\begin{array}{l}49.6 \\
50.4\end{array}$ & $\begin{array}{l}58.0 \\
42.0\end{array}$ & $\begin{array}{l}55.2 \\
44.8\end{array}$ & $\begin{array}{l}52.9 \\
47.1\end{array}$ \\
\hline $\begin{array}{l}\text { Position in Household } \\
\text { Head } \\
\text { Spouse }\end{array}$ & $\begin{array}{l}55.2 \\
44.8\end{array}$ & $\begin{array}{l}59.2 \\
40.8\end{array}$ & $\begin{array}{l}76.8 \\
23.2\end{array}$ & $\begin{array}{l}62.4 \\
37.6\end{array}$ & $\begin{array}{l}63.4 \\
36.6 \\
\end{array}$ \\
\hline $\begin{array}{l}\text { Language } \\
\text { Castellano } \\
\text { Aymara } \\
\text { Quechua } \\
\text { Guarani }\end{array}$ & $\begin{array}{r}58.0 \\
0.0 \\
0.0 \\
42.0\end{array}$ & $\begin{array}{r}2.0 \\
0.0 \\
98.0 \\
0.0\end{array}$ & $\begin{array}{r}5.6 \\
94.4 \\
0.0 \\
0.0\end{array}$ & $\begin{array}{r}95.6 \\
0.0 \\
4.4 \\
0.0\end{array}$ & $\begin{array}{l}40.3 \\
23.6 \\
25.6 \\
10.5\end{array}$ \\
\hline $\begin{array}{l}\text { Religion } \\
\text { Catholic } \\
\text { Evangelical Protestant } \\
\text { Other }\end{array}$ & $\begin{array}{r}74.4 \\
24.0 \\
1.6\end{array}$ & $\begin{array}{r}94.4 \\
4.8 \\
0.8\end{array}$ & $\begin{array}{r}77.6 \\
21.2 \\
1.2\end{array}$ & $\begin{array}{r}94.4 \\
4.4 \\
1.2\end{array}$ & $\begin{array}{r}85.2 \\
13.6 \\
1.2\end{array}$ \\
\hline $\begin{array}{l}\text { Average years lived in } \\
\text { community }\end{array}$ & 30.1 & 33.4 & 44.2 & 32.5 & 35.0 \\
\hline
\end{tabular}

Table 2 also indicates the linguistic diversity of Bolivia: indigenous languages dominate in Mizque (Quechua) and Tiahuanacu (Aymara), while Spanish is spoken the most in Villa Serrano and Charagua. The majority of the population is Catholic, but important Protestant groups live in Charagua and Tiahuanacu.

5 For further details on the sampling procedure and the survey field work, see Sandoval et al, 1998. 
Table 3 provides a broad breakdown of some of the key economic characteristics of the households in the sample. ${ }^{6}$ Slightly more than one-fifth of the adult sample population is inactive. This figure is higher in Charagua. Roughly $80 \%$ of economically active household members are farmers. The vast majority of economically active people work as self-employed or unpaid family workers. Only in Charagua is there a significant percentage of wage earners.

One-fifth of the sample population received no education and more than one-half of the population have no education past the primary level. Among the four municipalities, Charagua does notably better than the others in terms of educational achievement: only $7 \%$ of the population have no education and almost one-third have been able to advance past the primary level. Graduates of vocational schools or universities are very rare in the four municipalities.

Table 3: Employment and Education Characteristics of the Sample (in \%) (for those older than 14 years of age)

\begin{tabular}{|c|c|c|c|c|c|}
\hline & Charagua & Mizque & Tiahuanacu & $\begin{array}{c}\text { Villa } \\
\text { Serrano }\end{array}$ & All \\
\hline \multicolumn{6}{|l|}{ Main Occupation } \\
\hline Farmer & 55.7 & 72.7 & 69.3 & 62.0 & 64.6 \\
\hline Trade & 0.3 & 4.4 & 4.2 & 3.3 & 3.0 \\
\hline Other Private Sector & 8.1 & 4.6 & 8.5 & 11.8 & 8.3 \\
\hline Public Sector & 5.5 & 1.4 & 1.1 & 3.8 & 3.1 \\
\hline Inactive & 30.5 & 17.0 & 17.0 & 19.2 & 21.2 \\
\hline All & 100.0 & 100.0 & 100.0 & 100.0 & 100.0 \\
\hline \multicolumn{6}{|l|}{ Employment Status of } \\
\hline Wage Earner & 26.5 & 6.8 & 6.5 & 9.1 & 11.7 \\
\hline Self-employed & 31.0 & 36.3 & 9.9 & 46.5 & 30.8 \\
\hline Unpaid Family Worker & 42.4 & 56.9 & 83.5 & 44.4 & 57.5 \\
\hline All & 100.0 & 10.0 & 100.0 & 100.0 & 100.0 \\
\hline \multicolumn{6}{|l|}{ Education } \\
\hline None & 7.1 & 22.9 & 28.8 & 24.9 & 20.6 \\
\hline Primary Incomplete & 45.2 & 38.7 & 30.2 & 42.8 & 39.5 \\
\hline Primary Complete & 15.6 & 18.8 & 12.6 & 12.6 & 14.9 \\
\hline Secondary Incomplete & 22.1 & 16.5 & 18.2 & 8.9 & 16.4 \\
\hline Secondary Complete & 5.7 & 2.0 & 6.9 & 2.6 & 4.3 \\
\hline Vocational & 3.6 & 0.8 & 1.2 & 4.5 & 2.6 \\
\hline University & 0.5 & 0.3 & 2.0 & 2.3 & 1.3 \\
\hline Other & 0.1 & 0.0 & 0.0 & 1.4 & 0.4 \\
\hline All & 100.0 & 100.0 & 100.0 & 100.0 & 100.0 \\
\hline
\end{tabular}

The pattern of household expenditure shows only slight differences across the four study zones (Table 4) although the levels of expenditures do differ a great deal. Mizque is

6 It is to be noted that Table 3 is calculated over all adult individuals in the sample, whilst Table 2 pertained only to the respondents. 
the richest province with an average annual household expenditure per capita of Bs. 2,503 per year. Charagua and Tiahuanacu have expenditure levels of respectively Bs. 1,857 and Bs. 1,768 per year, while Villa Serrano has the lowest annual household expenditure per capita at Bs. 1,502 per year, almost $40 \%$ below that of Mizque. The Gini-coefficient over the four study zones is 0.37 , which is lower than 0.42 reported for the country as a whole (World Bank, 1999). Among the four municipalities, Tiahuanacu has the most equal distribution, while Charagua has the most uneven. This is particularly noticeable when comparing the ratio of the richest over the poorest village which is almost twice as high in Charagua than in Tiahuanacu. We have also calculated the relative incidence of poverty based on a poverty line determined as two-thirds of the median household expenditure per capita for the four municipalities. In line with the observed differences in average expenditure per capita, Villa Serrano records the highest poverty incidence at 33\%, while the lowest incidence is in Mizque at 9\%. The expenditure gap follows the same pattern.

Table 4: The Level and Composition of Household Expenditure (mean of ratios)

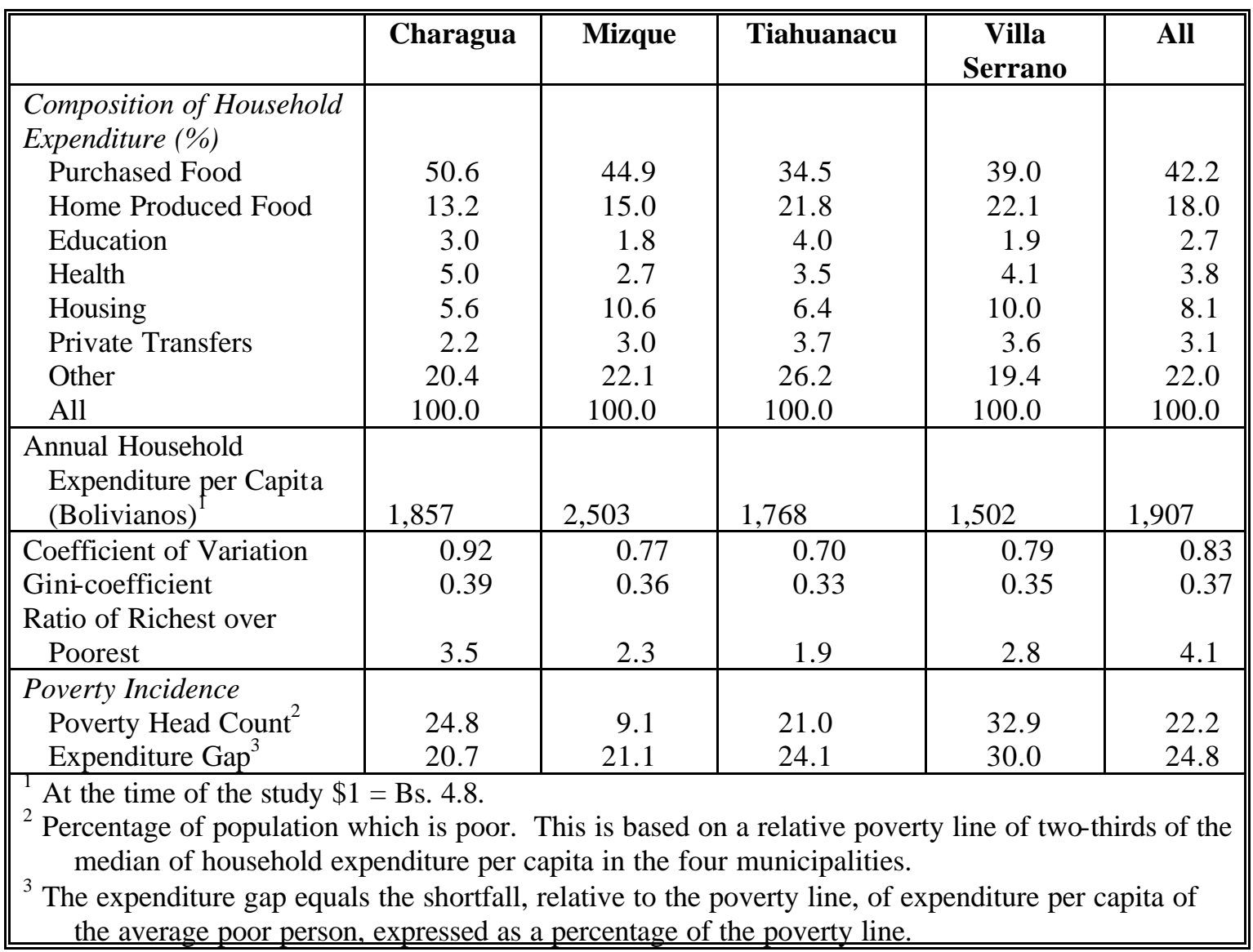

Household welfare is not measured only by the level of expenditures but also by various other dimensions. Table 5 contains several dimensions which can be calculated from the LLI data set. Specifically, we show indicators relating to how often the household goes hungry, the forced sale of assets in order to buy necessities, the number of 
children aged 5-14 who do not attend school, and access to tap water and electricity. The data are shown by quintiles which rank households based on household expenditure per capita. Table 5 suggests that $25 \%$ of sample households indicate that they often go hungry in the course of the year. However, the rate is much higher $(38.5 \%)$ among the poorest households. About 1 in 5 households declared that in the past year they had to sell livestock or equipment in order to buy necessities. This figures varies less pronouncedly by quintile and is actually slightly higher for the richer households (presumably because they have more assets to sell). In the two poorest quintiles, more than $22 \%$ of households do not send all of their children to school, while in the richest quintile this is only $5.5 \%$. In addition, $11.7 \%$ of households had to pull children out of school in order to work at home or to work on the farm. However, the incidence of this is three times as high in the poorest as in the richest quintile. In terms of access to amenities, electricity is significantly more available to the rich than to the poor although access to tap water is fairly even across the five quintiles.

Table 5: Selected Indicators of Households Well-being

\begin{tabular}{|c|c|c|c|c|c|c|}
\hline \multirow[b]{2}{*}{ Percent of Households } & \multicolumn{5}{|c|}{ Quintile } & \multirow[b]{2}{*}{ All } \\
\hline & Poorest & 2 & 3 & 4 & Richest & \\
\hline Which often go hungry & 38.5 & 30.0 & 24.5 & 19.5 & 13.5 & 25.2 \\
\hline $\begin{array}{l}\text { Which sold land, livestock } \\
\text { or equipment in order to } \\
\text { buy necessities }\end{array}$ & 19.5 & 18.5 & 26.0 & 25.5 & 24.0 & 22.7 \\
\hline $\begin{array}{l}\text { Where not all children 5-14 } \\
\text { attend school }\end{array}$ & 22.3 & 22.5 & 16.9 & 18.2 & 5.5 & 18.4 \\
\hline $\begin{array}{l}\text { Which pulled boys out of } \\
\text { school to help on farm or at } \\
\text { home }\end{array}$ & 9.9 & 6.7 & 6.8 & 7.3 & 2.5 & 7.1 \\
\hline $\begin{array}{l}\text { Which pulled girls out of } \\
\text { school to help on farm or at } \\
\text { home }\end{array}$ & 7.5 & 6.7 & 6.8 & 5.5 & 2.5 & 6.2 \\
\hline $\begin{array}{l}\text { Which pulled children out } \\
\text { of school to help on farm or } \\
\text { at home }\end{array}$ & 15.5 & 12.1 & 11.4 & 11.0 & 4.9 & 11.7 \\
\hline With access to electricity & 12.5 & 18.0 & 23.5 & 40.0 & 57.5 & 30.3 \\
\hline With access to tap water & 45.5 & 49.0 & 51.0 & 52.0 & 60.5 & 51.6 \\
\hline
\end{tabular}

Table 6 shows the ownership of various asets by households, such as durable goods, land and animals. The durable goods most frequently owned by the sample households are a radio (present in almost two-thirds of all households), an audio system, a bicycle, and a sewing machine. Overall, asset ownership is slightly higher in Tiahuanacu, which is probably explained by its proximity to La Paz, which improves access to such assets, and in Mizque which also has the highest per capita expenditures. Overall asset ownership is lowest in Villa Serrano. Ownership of animals is quite high in the study area: each household owns on average 20 large animals, and the variation across the four provinces is slight. The average household also owns 3.8 hectares of land. However, in 
Charagua the average land ownership is somewhat higher at 5.0 hectares, while in Mizque it is lowest at only 2.5 hectares.

From a social capital perspective, ease of communication is important. The municipalities differ in their overall access to communication and hence accessibility and ease of networking. Once again Mizque and Tiahuanacu lead the other two provinces. Close to $50 \%$ of households in Mizque have access to electricity, $40 \%$ in Tiahuanacu, $22 \%$ in Charagua and $10 \%$ in Villa Serrano.

Table 6: Ownership of Household Durables, Land and Animals

\begin{tabular}{|c|c|c|c|c|c|}
\hline & Charagua & Mizque & Tiahuanacu & $\begin{array}{c}\text { Villa } \\
\text { Serrano }\end{array}$ & All \\
\hline \multicolumn{6}{|l|}{ Percent of Households } \\
\hline $\begin{array}{l}\text { Owning } \\
\text { Car/Truck }\end{array}$ & 1.2 & 4.0 & 2.0 & 1.6 & 2.2 \\
\hline Boat & 0.0 & 0.0 & 11.6 & 0.0 & 2.9 \\
\hline Outboard Motor & 0.4 & 0.8 & 0.4 & 0.0 & 0.4 \\
\hline Motorcycle/Moped & 1.6 & 6.4 & 3.2 & 2.0 & 3.3 \\
\hline Bicycle & 44.8 & 50.8 & 55.6 & 12.4 & 40.9 \\
\hline Color TV & 5.6 & 8.0 & 4.4 & 2.4 & 5.1 \\
\hline Black/White TV & 6.8 & 6.4 & 12.0 & 6.0 & 7.8 \\
\hline Audio System & 36.0 & 41.6 & 48.4 & 50.4 & 44.1 \\
\hline Telephone & 3.2 & 2.0 & 3.2 & 0.8 & 2.3 \\
\hline Radio & 64.4 & 58.8 & 82.4 & 54.4 & 65.0 \\
\hline Refrigerator/Freezer & 9.2 & 10.4 & 3.2 & 5.2 & 7.0 \\
\hline Sewing Machine & 19.2 & 22.8 & 33.2 & 26.0 & 25.3 \\
\hline Washing Machine/Dryer & 0.4 & 0.8 & 0.8 & 0.4 & 0.6 \\
\hline Pressure Lamp & 1.6 & 24.0 & 3.6 & 9.2 & 9.6 \\
\hline Other Major Durable & 4.0 & 4.8 & 3.6 & 17.2 & 7.4 \\
\hline Average Asset Score & 2.0 & 2.4 & 2.7 & 1.9 & 2.2 \\
\hline $\begin{array}{l}\text { Average Number of Large } \\
\text { Animals Owned }\end{array}$ & 22.8 & 16.1 & 21.2 & 17.8 & 19.5 \\
\hline $\begin{array}{l}\text { Average Hectares of Land } \\
\text { Owned or Rented }\end{array}$ & 5.0 & 2.5 & 3.9 & 3.7 & 3.8 \\
\hline
\end{tabular}

In summary, the LLI sample shows four very diverse municipalities. Mizque, in Bolivia's Central Valleys, is characterized by intensive agriculture on small plots of land and is the richest area. Charagua in the eastern plains of the country is the most linguistically and religiously diverse municipality. It has the highest education level and the highest prevalence of wage employment, but is also characterized by the most unequal distribution of household expenditure. Tiahuanacu is close to $\mathrm{La} \mathrm{Paz}$, and is characterized by subsistence farming and a slightly below average household expenditure level. Lastly, Villa Serrano, in the valleys of southern Bolivia, is the poorest of the four study zones. 


\section{THE MAP OF LOCAL INSTITUTIONS}

The LLI questionnaire includes a large section to record the number of organizations and households' memberships in these organizations. Overall, 67 different types of organizations were recorded in the four municipalities. The total membership in these organizations was 1,432. Thus, the average households belonged to 1.4 groups and associations. This density is much lower than in the two other countries in the LLI study: in both Indonesia and Burkina Faso, the average household belongs to 6 groups (although in the case of Burkina Faso, most of these memberships were not active). The disaggregation in categories of groups reported in Table 7 is parallel to the other countries to allow a comparison. However the rest of the report recombines groups to reduce the number of categories and to reflect a functional distribution of groups and memberships.

The landscape of local institutions is dominated by the presence of agrarian syndicates (sindicatos campesinos). Although these were created by the state during the land redistribution reforms of 1952 , over time they have come to function as the central community organization group. Agrarian syndicates are largely perceived to be managing community resources ranging from land, forests, and water to resolving conflict. The number of memberships in agrarian syndicates varies by municipality.

\section{Table 7: Active Memberships in Local Institutions, by Municipality (original classification)}

\begin{tabular}{||l|c|c|c|c|c|c|c|c|c|c||}
\hline \multirow{2}{*}{} & \multicolumn{2}{|c|}{ Tiahuanacu } & \multicolumn{2}{|c|}{ Villa Serrano } & \multicolumn{2}{c|}{ Mizque } & \multicolumn{2}{c|}{ Charagua } & All & $\begin{array}{c}\% \text { of } \\
\text { Total }\end{array}$ \\
\cline { 2 - 12 } & Total & $\%$ & Total & $\%$ & Total & $\%$ & Total & $\%$ & & \\
\hline Community-Wide Organizations & 238 & 54.0 & 119 & 31.2 & 237 & 72.3 & 46 & 16.3 & 640 & 44.7 \\
Sub-community Gender Groups & 4 & 0.9 & 37 & 9.7 & 22 & 6.7 & 61 & 21.6 & 124 & 8.7 \\
Sub-community Generation Groups & 1 & 0.2 & 1 & 0.3 & 0 & 0.0 & 4 & 1.4 & 6 & 0.4 \\
Religious Groups & 17 & 3.9 & 15 & 3.9 & 2 & 0.6 & 21 & 7.4 & 55 & 3.8 \\
Social Service Groups & 0 & 0.0 & 0 & 0.0 & 0 & 0.0 & 0 & 0.0 & 0 & 0.0 \\
Environmental Service Groups & 2 & 0.5 & 4 & 1.0 & 0 & 0.0 & 0 & 0.0 & 6 & 0.4 \\
Productive Groups & 20 & 4.5 & 12 & 3.1 & 7 & 2.1 & 66 & 23.4 & 105 & 7.3 \\
Labor Groups & 3 & 0.7 & 3 & 0.8 & 2 & 0.6 & 1 & 0.4 & 9 & 0.6 \\
Natural Resource Management & & & & & & & & & & \\
Groups & 0 & 0.0 & 21 & 5.5 & 12 & 3.7 & 6 & 2.1 & 39 & 2.7 \\
Credit/Finance Groups & 2 & 0.5 & 0 & 0.0 & 9 & 2.7 & 0 & 0.0 & 11 & 0.8 \\
Marketing Groups & 0 & 0.0 & 1 & 0.3 & 4 & 1.2 & 1 & 0.4 & 6 & 0.4 \\
Supra-community Level & & & & & & & & & & \\
Membership Organizations & 22 & 5.0 & 41 & 10.8 & 13 & 4.0 & 2 & 0.7 & 78 & 5.4 \\
Recreational Groups & 18 & 4.1 & 0 & 0.0 & 6 & 1.8 & 6 & 2.1 & 30 & 2.1 \\
Other & 114 & 25.9 & 127 & 33.3 & 14 & 4.3 & 68 & 24.1 & 323 & 22.6 \\
Total & 441 & 100.0 & 381 & 100.0 & 328 & 100.0 & 282 & 100.0 & 1432 & 100.0 \\
\hline \hline
\end{tabular}

Memberships in groups managed by women are the next most prevalent category, totaling $9 \%$ of memberships. These include: mothers clubs, originally created to channel food distribution, but which now primarily focus on sewing, kitchen gardens, and provision of school breakfasts; women's syndicates established to represent women's 
demands since the creation of the agrarian syndicates; women's "food for work" groups; and a small number of women's credit groups.

About $7 \%$ of all memberships are in a variety of production-oriented groups. These include agricultural producers groups, livestock groups, artisan, trade and a range of other commercially-oriented groups. Smaller numbers of memberships are in environmental groups $(0.4 \%)$, labor groups $(0.6 \%)$, natural resource management groups $(2.7 \%)$, and credit and finance groups $(0.8 \%)$.

The total number of reported memberships in religious groups is surprisingly small, $3.8 \%$. However, this may be a function of the way people interpreted the question rather than reflecting church attendance.

Linkage organizations or supra-community organizations accounted for $5 \%$ of all memberships. These include syndicate organizations at the cantonal, provincial and departmental levels as well as other associations that represented particular types of groups across communities. These included sports, religious, commercial, infrastructure, trade and women's groups.

Table 8 reports the distribution of organizations and memberships based on a reclassification of groups by function. While agrarian syndicates still dominate the landscape of membership in local level institutions, membership in productive groups (12\%), health/education groups (7\%) and social service groups (9\%) emerge more strongly. Memberships in supra-community organizations also increases to $7.5 \%$. There is also a clearer demarcation of NGOs (14\%), most of which in effect also have an important cross-community linkage function. NGOs include international NGOs such as CARE and CARITAS and a range of strong local NGOs such as PLAFOR (Plan Forestal), CIAT (Centro de Investigacíon Agropecuaria del Trópico) and FONDECO (Fondo de Desarrollo Comunal).

Table 8: Number of Local Organizations and Number of Memberships (functional classification)

\begin{tabular}{||l|c|c|c|l||}
\hline \multicolumn{1}{|c|}{ Type of Group } & $\begin{array}{c}\text { Number of } \\
\text { Organizations }\end{array}$ & $\begin{array}{c}\text { Number of Active } \\
\text { Memberships }\end{array}$ & Percent & \multicolumn{1}{|c||}{ Examples } \\
\hline Agrarian Syndicates & 3 & 640 & 44.7 & Captaincy, syndicates \\
\hline Productive Groups & 19 & 173 & 12.1 & $\begin{array}{l}\text { Agricultural producers, } \\
\text { livestock, construction, } \\
\text { water, irrigation committees }\end{array}$ \\
\hline $\begin{array}{l}\text { Education/Health } \\
\text { Groups }\end{array}$ & 8 & 103 & 7.2 & $\begin{array}{l}\text { School boards, health } \\
\text { committees, literacy groups }\end{array}$ \\
\hline Social Service Groups & 14 & 132 & 9.2 & Mothers clubs, youth groups \\
\hline Religious Groups & 6 & 55 & 3.8 & Church groups \\
\hline Government Groups & 2 & 24 & 1.7 & State representatives \\
\hline $\begin{array}{l}\text { Supra-community } \\
\text { Groups }\end{array}$ & 12 & 108 & 7.5 & $\begin{array}{l}\text { Cross-community groups: } \\
\text { sports, syndicates, road } \\
\text { groups }\end{array}$ \\
\hline NGO Groups & 3 & 197 & 13.8 & Bolivian and international \\
\hline Total & 67 & 1432 & 100.0 & \\
\hline \hline
\end{tabular}


Table 9 reports the distribution of memberships across groups by municipality and Table 10 reports the distribution of households participating in local organizations by municipality. It is important to note that most households in Mizque and Tiahuanacu are active members of agrarian syndicates but that this is true for only $50 \%$ of households in Villa Serrano and less than $20 \%$ of households in Charagua. ${ }^{7}$ As is explored in more detail in the later section on measuring social capital, in municipalities where the syndicate is not active or excludes the poor, other organizations that focus on improving livelihoods or education and health emerge to play important roles in people's lives. Thus, over $25 \%$ of households in Charagua belong to social service clubs and to productive groups. In Villa Serrano, over $20 \%$ belong to education and health groups. Most of these groups are either community initiated or initiated by NGOs.

Table 9: Active Memberships in Local Institutions, by Municipality

\begin{tabular}{||l|c|c|c|c|c|c|c|c|c|c||}
\hline \hline & \multicolumn{2}{|c|}{ Tiahuanacu } & \multicolumn{2}{|c|}{$\begin{array}{c}\text { Villa } \\
\text { Serrano }\end{array}$} & \multicolumn{2}{c|}{ Mizque } & \multicolumn{2}{c|}{ Charagua } & All & $\begin{array}{c}\text { \% of } \\
\text { Total }\end{array}$ \\
\cline { 2 - 12 } & Total & $\%$ & Total & $\%$ & Total & $\%$ & Total & $\%$ & & \\
\hline Agrarian Syndicates & 238 & 54.0 & 119 & 31.2 & 237 & 72.3 & 46 & 16.3 & 640 & 44.7 \\
Productive Groups & 25 & 5.7 & 39 & 10.2 & 34 & 10.4 & 75 & 26.6 & 173 & 12.1 \\
Education/Health & & & & & & & & & & \\
$\quad$ Groups & 29 & 6.6 & 59 & 15.5 & 8 & 2.4 & 7 & 2.5 & 103 & 7.2 \\
Social Service Groups & 9 & 2.0 & 36 & 9.4 & 22 & 6.7 & 65 & 23.0 & 132 & 9.2 \\
Religious Groups & 17 & 3.9 & 15 & 3.9 & 2 & 0.6 & 21 & 7.4 & 55 & 3.8 \\
Government Groups & 8 & 1.8 & 12 & 3.1 & 0 & 0.0 & 4 & 1.4 & 24 & 1.7 \\
Supra-community & & & & & & & & & & \\
$\quad$ Groups & 40 & 9.1 & 41 & 10.8 & 19 & 5.8 & 8 & 2.8 & 108 & 7.5 \\
NGO Groups & 75 & 17.0 & 60 & 15.7 & 6 & 1.8 & 56 & 19.9 & 197 & 13.8 \\
Total & 441 & 100.0 & 381 & 100.0 & 328 & 100.0 & 282 & 100.0 & 1432 & 100.0 \\
\hline
\end{tabular}

Table 10: Percentage of Households Participating in Local Associations, by Region

\begin{tabular}{||l|c|c|c|c|c||}
\hline \hline & Tiahuanacu & Villa Serrano & Mizque & Charagua & All \\
\hline Agrarian Syndicates & 92.8 & 47.6 & 91.2 & 18.0 & 62.4 \\
Productive Groups & 10.0 & 13.2 & 12.4 & 28.0 & 15.9 \\
Education/Health Groups & 11.2 & 21.2 & 3.2 & 2.8 & 9.6 \\
Social Service Groups & 3.6 & 14.4 & 8.4 & 25.2 & 12.9 \\
Religious Groups & 6.8 & 6.0 & 0.8 & 8.4 & 5.5 \\
Government Groups & 3.2 & 3.6 & 0.0 & 1.2 & 2.0 \\
Supra-community Groups & 15.2 & 14.0 & 7.6 & 3.2 & 10.0 \\
NGO Groups & 24.4 & 18.4 & 2.0 & 21.2 & 16.5 \\
\hline \hline
\end{tabular}

7 In principle, membership in agrarian syndicates is mandatory. Household res ponses to the membership question capture the household's assessment of whether it is an active participant in the syndicate's affairs. 
As is shown in Table 11 groups only for men are the most common (43\%). The number of women-only groups is $20 \%$. The rest, 37\%, are mixed. As mentioned before, this reflects the dominance of the agrarian syndicates in which leadership revolves among heads of households who are primarily male. Since every household is already represented by males, it is likely that these groups are viewed as male-only groups. It is precisely for this reason that in some areas women have created their own women-only syndicates to address their needs. The Law of Popular Participation which has given legal recognition to territorial organizations such as the agrarian syndicates, which are dominated by men, has unknowingly excluded women's representation, both in terms of interests as well as in terms of leadership. It is interesting to note that women-only groups are the highest, $26 \%$, in Charagua which has the largest number of NGOs. Villa Serrano, which has the second highest number of women-only groups, has an increasing number of NGOs.

In terms of age, although there are some youth groups and groups to take care of the needs of the elderly, most groups attract men and women in their middle years.

Table 11: Distribution of Associational Memberships, by Gender and Age

\begin{tabular}{||l|c|c|c|c|c||}
\hline & Tiahuanacu & Villa Serrano & Mizque & Charagua & All \\
\hline Gender & & & & & \\
- Female only & 17.2 & 21.3 & 16.2 & 25.9 & 19.8 \\
- Male only & 29.5 & 29.7 & 72.3 & 48.2 & 43.0 \\
- Mixed & 53.3 & 49.1 & 11.6 & 25.9 & 37.2 \\
All & 100.0 & 100.0 & 100.0 & 100.0 & 100.0 \\
\hline Age & & & & & \\
- Under 25 Years & 6.3 & 1.8 & 4.0 & 3.9 & 4.1 \\
- 25 + Years & 64.4 & 82.9 & 84.8 & 82.3 & 77.5 \\
- Mixed & 29.3 & 15.2 & 11.3 & 13.8 & 18.4 \\
All & 100.0 & 100.0 & 100.0 & 100.0 & 100.0 \\
\hline
\end{tabular}

Since households belong to only 1.4 associations on average, and given the dominance of agrarian syndicates, it is not surprising that households consider most associations to which they belong as very important (Table 12a). The only association for which this is less true is memberships in NGOs. When the distribution is examined only for the groups that households considered the most important, the pattern of results almost completely reflects the overall patterns of membership, i.e. agrarian syndicates emerge as the most important, followed by productive groups (Table 12b). Overall, 12\% of the very important memberships are in NGOs and another 7\% were in supra-community groups. 
Table 12a: Distribution (\%) of Ratings of Importance of Associations

\begin{tabular}{||l|c|c|c|c||}
\hline Groups & $\begin{array}{c}\text { Very } \\
\text { Important }\end{array}$ & $\begin{array}{c}\text { Somewhat } \\
\text { Important }\end{array}$ & $\begin{array}{c}\text { Not } \\
\text { Important }\end{array}$ & Total \\
\hline Agrarian Syndicates & 89.7 & 8.4 & 1.9 & 100.0 \\
Productive Groups & 87.9 & 12.1 & 0.0 & 100.0 \\
Education/Health Groups & 89.3 & 8.7 & 1.9 & 100.0 \\
Social Service Groups & 81.8 & 17.4 & 0.8 & 100.0 \\
Religious Groups & 87.3 & 10.9 & 1.8 & 100.0 \\
Government Groups & 83.3 & 16.7 & 0.0 & 100.0 \\
Supra-community Groups & 83.3 & 13.9 & 2.8 & 100.0 \\
NGO Groups & 77.7 & 20.8 & 1.5 & 100.0 \\
\hline
\end{tabular}

Table 12b: Distribution (\%) of Memberships in Associations Considered Very Important

\begin{tabular}{||l|c||}
\hline Groups & Very Important \\
\hline Agrarian Syndicates & 46.4 \\
Productive Groups & 12.3 \\
Education/Health Groups & 7.4 \\
Social Service Groups & 8.7 \\
Religious Groups & 3.9 \\
Government Groups & 1.6 \\
Supra-community Groups & 7.3 \\
NGO Groups & 12.4 \\
Total & 100.00 \\
\hline
\end{tabular}

The distribution of the most important groups was also examined across the four municipalities. Consistent with other findings, agrarian syndicates were the most prominent in Mizque and Tiahuanacu and productive, health/education and social service groups were the most important in Charagua and Villa Serrano.

To further understand which specific associations are considered the most important in people's lives, Table 13 reports the ten most important specific groups reported by households. As expected, the agrarian synd icates appear at the top of this list. What is important to note is that despite the creation of these groups by the state almost 50 years ago, they have been in existence long enough to be considered by respondents as having been initiated by communities. The second group in the list is NGOs, mentioned as the most important group by $14 \%$ of households. NGOs perform important functions either in the absence of effective local government or in the absence of effective traditional organizations, which is especially the case for Charagua and Villa Serrano. This pattern of substitution and complementarity will be discussed further in the next section. ${ }^{8}$ NGOs are, however, seen as being initiated by outsiders.

8 For an in -depth discussion see Narayan (1999). 
The community is the source of most associations in all categories, except for religious groups and NGO groups, which are seen as having been initiated outside the community (Table 14). Government sponsored groups are of course categorized primarily as initiated by the state. In addition to official state bodies, this category includes associations created by the Social Investment Fund and Rural Development Fund. It is also striking that all categories of local associations in Bolivia rely strongly on a formal organizational structure (Table 14). Only education/health groups and social service groups are informally organized to some degree.

Table 13: The Ten Most Important Local Associations

\begin{tabular}{||l|l|c|c|c||}
\hline \hline \multicolumn{1}{|c|}{ Group Name } & Category & $\begin{array}{c}\text { Initiated by } \\
\text { Government, } \\
\text { Community or } \\
\text { Outside } \\
\text { Community }\end{array}$ & $\begin{array}{c}\text { Formal/ } \\
\text { Informal } \\
\text { Group }\end{array}$ & $\begin{array}{c}\text { Times Cited } \\
\text { (\% of Total } \\
\text { Citations) }\end{array}$ \\
\hline 1. Agrarian Syndicate & $\begin{array}{l}\text { Sindicatos } \\
\text { Campesinos }\end{array}$ & C & F & $584(41.3 \%)$ \\
\hline 2. Non-denominational NGOs & NGO Groups & O & F & $194(13.7 \%)$ \\
\hline 3. Mothers Club & $\begin{array}{l}\text { Social } \\
\text { Service }\end{array}$ & C/O & F/I & $65(4.6 \%)$ \\
\hline $\begin{array}{l}\text { 4. Agricultural Producer's Association } \\
\text { (Work Groups) }\end{array}$ & $\begin{array}{l}\text { Productive } \\
\text { Groups }\end{array}$ & C/O & F & $60(4.2 \%)$ \\
\hline 5. Denominational NGOs & NGO Groups & O & F & $48(3.4 \%)$ \\
\hline 6. Women's Center & $\begin{array}{l}\text { Social } \\
\text { Service }\end{array}$ & C/O & F/I & $46(3.3 \%)$ \\
\hline 7. Captaincy & $\begin{array}{l}\text { Sindicatos } \\
\text { Campesinos }\end{array}$ & C & F & $43(3.0 \%)$ \\
\hline $\begin{array}{l}\text { 8. Central/Sub-central } \\
\text { Association/Federation of Rural People }\end{array}$ & $\begin{array}{l}\text { Sindicatos } \\
\text { Campesinos }\end{array}$ & C & F & $39(2.8 \%)$ \\
\hline 9. Heads of Family Association & $\begin{array}{l}\text { Education/ } \\
\text { Health }\end{array}$ & C & F & $39(2.8 \%)$ \\
\hline 10. Informal Education Group & $\begin{array}{l}\text { Education/ } \\
\text { Health }\end{array}$ & O & F/I & $23(1.6 \%)$ \\
\hline \hline
\end{tabular}

Table 14: Type of Initiation and Organization of Groups

\begin{tabular}{||l|c|c|c|c|c||}
\hline \hline & \multicolumn{3}{|c|}{ Initiation } & \multicolumn{2}{c||}{ Organization } \\
\cline { 2 - 6 } & State & Community & $\begin{array}{c}\text { Outside } \\
\text { Community }\end{array}$ & Formal & Informal \\
\hline Agrarian Syndicates & 10.9 & 84.5 & 4.5 & 96.4 & 3.6 \\
Productive Groups & 6.9 & 65.9 & 27.2 & 92.5 & 7.5 \\
Education/Health Groups & 6.8 & 63.1 & 30.1 & 82.5 & 17.5 \\
Social Service Groups & 6.1 & 60.6 & 33.3 & 75.0 & 25.0 \\
Religious Groups & 3.6 & 32.7 & 63.6 & 94.6 & 5.5 \\
Government Groups & 70.8 & 16.7 & 12.5 & 91.7 & 8.3 \\
Supra-community Groups & 7.4 & 83.3 & 9.3 & 90.7 & 9.3 \\
NGO Groups & 3.6 & 8.1 & 88.3 & 87.8 & 12.2 \\
\hline \hline
\end{tabular}


Households in the sample have a surprisingly high community or collective orientation. Close to $50 \%$ of households said that the main reason for joining groups is the expected impact on the whole community (Table 15). This is probably a reflection of two factors. Many rural communities are composed primarily of indigenous people who still live in solidarity with each other. Second, this finding reflects the primary role of the agrarian syndicates. It is interesting to contrast this figure with Indonesia, which at the community level used to have strong traditions of gotong royong, or collective participation and self-help. Yet, in Indonesia, only $19 \%$ of households listed the community as a prime reason for joining groups. In Bolivia, the other main reason for joining groups was the expected benefits to household livelihood. Only 13\% said that they belonged to groups because membership was mandatory. This result, together with the fact that most groups are seen as community-initiated, attests to the fact that most groups appear to be serving a purpose in the lives of households and communities, and therefore people choose to participate in these groups.

Table 15: Reasons for Joining the Most Important Groups

\begin{tabular}{||l|c|c|c|c|c||}
\hline \hline Reasons for Joining (\%) & Tiahuanacu & $\begin{array}{c}\text { Villa } \\
\text { Serrano }\end{array}$ & Mizque & Charagua & All \\
\hline Impact on Household & 15.3 & 26.4 & 26.4 & 33.5 & 24.6 \\
Livelihood & 65.8 & 39.2 & 28.6 & 45.5 & 45.6 \\
Impact on Community & 3.4 & 9.1 & 8.1 & 1.9 & 5.7 \\
Everybody Belongs & 6.0 & 12.2 & 28.9 & 3.0 & 12.6 \\
Mandatory & 3.1 & 9.1 & 4.4 & 6.8 & 5.7 \\
Emergency/Future Benefit & 5.7 & 2.3 & 3.1 & 6.4 & 4.3 \\
Enjoyable & 0.8 & 1.7 & 0.6 & 3.0 & 1.4 \\
Other & 100.0 & 100.0 & 100.0 & 100.0 & 100.0 \\
Total & \multicolumn{4}{|r||}{} \\
\hline
\end{tabular}

Households were specifically asked if membership in groups improved their access to particular services. Table 16 reflects the fact that activities of the associations affect both communities as well as households. The most commonly reported benefits were in education (60\%), water and sanitation (42\%), health (38\%), land rights, (30\%), electricity (24\%), agricultural technology $(20 \%)$ and irrigation $(20 \%)$. The fact that these numbers are much higher than what the functional classification suggested (see Table 9) may reflect the fact that most groups serve multiple functions or have spillover effects in areas other than their designated primary function. It may also be a consequence of the way in which the question was asked. Most questions in the LLI questionnaire were asked in an open-ended manner and the interviewer coded the responses. However, for this question, all the service categories were read out and respondents were asked specifically if groups had been used to access the entire list of services reported in Table 16. 
Table 16: Involvement in Service Provision of the Most Important Groups

\begin{tabular}{||l|c|c|c|c|c||}
\hline Percent of Groups Active in & Tiahuanacu & $\begin{array}{c}\text { Villa } \\
\text { Serrano }\end{array}$ & Mizque & Charagua & All \\
\hline Education & 63.2 & 75.3 & 46.3 & 50.8 & 59.8 \\
Health & 33.7 & 44.0 & 36.0 & 39.5 & 38.2 \\
Water Supply and Sanitation & 28.0 & 48.3 & 53.4 & 39.8 & 41.9 \\
Electricity & 43.3 & 7.1 & 22.8 & 15.8 & 24.3 \\
Credit & 3.9 & 3.4 & 9.6 & 24.4 & 9.3 \\
Savings & 4.9 & 1.7 & 7.5 & 5.6 & 4.8 \\
Agricultural Inputs/Technology & 13.5 & 22.2 & 22.7 & 26.3 & 20.6 \\
Irrigation & 7.0 & 13.1 & 55.9 & 7.1 & 20.5 \\
Land, Forestry, Water Rights & 33.1 & 13.6 & 41.9 & 32.0 & 30.1 \\
\hline
\end{tabular}

Membership in groups provides a rich environment for social learning (Table 17). In addition, it can provide experiences in leadership. In most societies leadership possibilities are limited to the local elite. In Bolivia, by contrast, $50.9 \%$ of households in the poorest quintile report being able to take up leadership positions in groups. This figure differs little from the median and upper income groups (57\% and 51\% respectively). There are, however, strong differences between municipalities and these parallel to some extent the differences in income inequality. In Tiahuanacu, $80 \%$ of households in the poorest villages and $76 \%$ of households in the richest villages have been in leadership positions. In Villa Serrano, by contrast, households in the richest villages are more frequently in leadership positions (49\%) than households in the poorest villages (40\%). One should keep in mind the widespread poverty in rural Bolivia and the strong communal orientation in many indigenous communities. It is interesting to compare these figures with Indonesia, where only $18 \%$ of the poorest households have been in leadership positions, as compared to $29 \%$ of the richest households. 
Table 17: Leadership Positions in Local Associations, by Income Level

\begin{tabular}{||c|c||}
\hline & $\begin{array}{c}\text { \% of Households with } \\
\text { Leadership Positions in the } \\
\text { Most Important Associations }\end{array}$ \\
\hline Household Quintiles & 50.9 \\
Poorest & 55.3 \\
2 & 56.8 \\
3 & 53.3 \\
4 & 50.8 \\
Richest & \\
\hline Village Quintiles & 46.0 \\
Poorest & 66.1 \\
2 & 52.0 \\
3 & 60.6 \\
4 & 40.7 \\
Richest & \\
\hline Municipality & \\
\hline Tiahuanacu: & 80.7 \\
Poorest villages & 76.0 \\
Richest villages & \\
\hline Villa Serrano: & 39.8 \\
Poorest villages & 48.5 \\
Richest villages & 44.3 \\
\hline Mizque: & 45.3 \\
Poorest villages & 41.8 \\
Richest villages & 41.4 \\
\hline Charagua: & \\
Poorest villages & \\
Richest villages & \\
\hline
\end{tabular}




\section{COMPLEMENTARITY AND SUBSTITUTION BETWEen ORganizATIONS}

In order to understand the impact of associations, it is important to dig a little deeper into the dynamic interaction between institutions and to understand the evolution of these associations. For this purpose, we consider four types of organizations: agrarian syndicates, other local organizations, municipal government and linkage organizations, including some NGOs.

In Tiahuanacu, Mizque and Villa Serrano rural communities are represented by agrarian syndicates (sindicatos campesinos). These organizations date back to 1952 when they were created by the state as a mechanism for political control. As mentioned in the previous section, they have since evolved into an organization of local self-government which legitimizes the status of farmers as participants in the political and planning process. The Law of Popular Participation of 1994 gave the syndicates formal status as channels of communication with the municipal government. The eastern plains of Bolivia, however, have remained largely untouched by this process of agrarian reform and establishment of syndicates. Specifically in Charagua, rural communities are organized around the Regional Assembly of the Guarani people, which performs functions similar to those of the agrarian syndicates. However, the traditional captaincy position was in a semi-feudal relationship to hacienda owners which served to reinforce the subservient position of farmers, who were a source of cheap and reliable labor to the Hacienda owners.

Participation in agrarian syndicates is based on a rotation system which is found throughout the Andean region (Pearse, 1984; Booth et al, 1996). Heads of households who own land-parcels in the community must assume directive posts in the syndicate at least once (at the risk of receiving fines and penalties if they do not take their turn). The system requires an annual rotation in directors so that there is a broad participation of households in the management of the syndicate. This system makes a significant claim on available human resources, especially in Mizque and Tiahuanacu where the agrarian syndicates are well established. In Villa Serrano the rotation system is not applied and in Charagua the traditional Guarani pattern of hereditary captaincies is followed, hence leadership skills are not widely shared.

In addition to the agrarian syndicates, functional organizations (primarily of women and of producers) are active in each of the four municipalities. Their membership is voluntary and they are primarily oriented to imparting benefits on the family rather than on the community. The institutional history and strength of different types of organizations is different in the four selected municipalities. Tiahuanacu and Mizque have a strong organizational tradition which has preserved many of the indigenous patterns of organization. In contrast, Villa Serrano and Charagua have a weaker organizational tradition which was usurped in the service of the dominant group of landowners and timber and ranching interests. Both in Villa Serrano and in Charagua, because of the relative absence of agrarian syndicates and because of exclusionary practices, the poor belong to other organizations which have emerged, mainly thanks to the activities of NGOs. 
Mizque and Charagua are characterized by effective municipal government. In Mizque, municipal government is headed by an established campesino elite that has trained workers and incorporated technical procedures. In Charagua, municipal government is made up of ranchers and timber barons, but it is open to dialogue with the Guarani indigenous population. In Villa Serrano and Tiahuanacu, municipal government is relatively weak. In Tiahuanacu the elite has direct access to La Paz and bypasses the local structures (Sandoval et al, 1998).

Why is it that in Charagua municipal government is responsive and effective despite being dominated by particular economic interests that had previously suppressed local populations? To understand this we need to examine the role of linkage organizations including NGOs and the role of the Law of Popular Participation. Regional grassroots organizations and NGOs serve to link organizations together so as to increase negotiating power vis-à-vis the state and markets or to increase access to new information and resources. Regional grassroots leadership plays an important role in the interaction between the communities and the municipal government. It consists primarily of the directors of the supra-communal syndicate organization ("campesino central") which coordinates the activities of the communal syndicates. In Charagua, regional leadership consists of the directors of the Zonal Assemblies of the Guarani People which coordinates the actions of the Local Assemblies. This regional leadership constitutes an "intercommunity political arm" which is recognized both by the communities and the municipal government. They held the third leading position in the CUSTB in 1993 and won a seat in parliament in an alliance with Cárdenas's MRTKL (Albó, 1995). This new leadership and accompanying political clout has broken the hold hacienda owners had on the traditional captaincy of the Guarani people. It is this new regional Guarani Assembly, which is a blend of old and new in terms of organizational design, that has led to a new era of negotiation with the local elite. The relations between the dominant elite and the Guarani are now cordial rather than conflictual.

Among the other three municipalities, this regional leadership is the most effective and dyna mic in Mizque. In Tiahuanacu, regional leadership is still emerging while in Villa Serrano the weakness of regional leadership reflects the low overall presence of agrarian syndicates in that municipality (Sandoval et al, 1998).

Furthermore, in each of the four municipalities there are NGOs actively working in the areas of health, education and agricultural and livestock production. They play important direct roles in service provision and in reorienting regional leaders away from national political issues to regional development issues.

The Law of Popular Participation is beginning to have an impact by breaking up the hold of the former political elite on municipal decision making. Before the Law of Popular Participation, Civic Committees, consisting of the local elite, pressured both prefectures and the central government into channeling resources in favor of the dominant groups in each region. In Mizque, Charagua and Villa Serrano, the civic committee has almost ceased to function. In Tiahuanacu, there is still a Residents Committee that consists of townspeople who have emigrated to La Paz but who come each year to party and "show off" their social and economic progress. 
In summary, it is possible to classify the four municipalities along two axes - the strength of traditional institutions and the strength of regional grassroots leadership and municipal government — as in Figure 1.

\section{Figure 1. The Four Municipalities, by Strength of Institutions}

\begin{tabular}{l|l}
\multicolumn{2}{c}{ Strong institutional tradition } \\
Tiahuanacu & Mizque \\
Weak regional leadership & Strong regional leadership \\
\hline Ineffective municipal government & Effective municipal government \\
Villa Serrano & Charagua \\
\multicolumn{1}{c|}{ Weak institutional tradition }
\end{tabular}




\section{The Measurement of Social Capital}

Social capital is the norms, networks and social relations embedded in formal and informal institutions of society that enable people to coordinate action and achieve desired goals. All societies are rich in social capital. Most people belong to primary social groups - the family, kin groups, ethnic groups - as well as informal and formal associations. Bonding, solidarity or social cohesion provides the basis for reciprocity and exchanges within these groups. However when the power and resources of these social groups is limited, bridging or linking social capital with other groups becomes important to access different resources, information and power (Putnam, 1995; Portes and Landolt, 1996; Evans, 1996; Woolcock, 1997; Narayan, 1997). In the Bolivian context, solidarity within indigenous groups provides the foundation for identity and survival. Linkages between indigenous groups consolidate their resources and power and change their ability to be heard and to negotiate with the formal governance structures. The social relations and preferences within government structures are also important and influence their openness to inclusion of indigenous groups as well as their responsiveness to local needs and demands.

In this study, we construct a quantitative social capital measure which focuses on social capital in groups and associations and supra-community associations. Our index does not distinguish the latter explicitly because the number of supra-community or linkage organizations is numerically small in the data set. However their importance comes through in the in-depth qualitative data.

The effectiveness with which social capital in the form of local associations can fulfill its role in disseminating information, reducing opportunistic behavior, and facilitating collective decision making depends on many aspects of the association reflecting its structure, its membership, and its functioning. For this study, we focus on six aspects of local associations.

\section{(1) Density of Membership}

This is measured by the number of memberships of each household in existing associations. The provision of a map of local associations was one of the prime objectives of the LLI study and a complete inventory of all existing associations was made at the village level. Each household was then given that inventory and asked which associations they were a member of. The survey recorded 67 different organizations in the 40 communities in the study, for a total of 1,432 active memberships. This indicates that on average each household is a member of one or two associations. The most important of these is the agrarian syndicate, which as the previous section indicated, takes account of $45 \%$ of all memberships. It is therefore essential in the case of Bolivia that density of associations be measured separately for agrarian syndicates and other local institutions.

Table 18 indicates that in Tiahuanacu and Mizque, close to 90\% of households are active members of the agrarian syndicate. In Villa Serrano this is only $57 \%$ and in Charagua it is only $18 \%$. (As we indicated previously, agrarian syndicates are not active in 
Charagua and their functions are implemented by the Regional Assembly of the Guarani people. Given the similarities of functions, membership in this organization is tabulated under the heading of agrarian syndicate.) It is striking that active membership in agrarian syndicates declines steadily with a rising level of education. At an aggregate level, the correlation with income level is quite low, but this masks regional differences. Indeed, in the two municipalities with high active membership, membership is below average only in the richest quintile (Mizque) or the richest two quintiles (Tiahuanacu) (Table 19). In the two other municipalities, membership is below average in the poorest quintile, peaks in the second poorest quintile, and then declines steadily with rising income level. This suggests that in Charagua and Villa Serrano, the poorest households are to a significant degree excluded from active membership in the agrarian syndicates.

However, Villa Serrano and Charagua have the highest membership in other local organizations and this membership is strongest among the poorer households. This reflects the complementarity between different types of organizations. In Tiahuanacu and Mizque, the agrarian syndicates are very effective and are active in the provision of a wide range of services. It stands to reason that where this is not the case people create voluntary organizations to fill the void.

\section{(2) Heterogeneity Index}

As explained earlier, the LLI questionnaire identified the three most important associations for each household. For those associations a number of supplementary questions were asked including about the internal homogeneity of the group. This was rated according to nine criteria: neighborhood, kin group, occupation, economic status, religion, gender, age, level of education, and political affiliation. ${ }^{9}$ On that basis we constructed a score ranging from 0 to 9 for each of the three groups (a value of 1 on each criterion indicates that members of the association were "mostly from different" kin group, economic status, etc.). The score of the three groups was averaged and the resulting index was re-scaled from 0 to 100 , whereby 100 corresponds to the highest possible value of the index. ${ }^{10}$ The average score of the heterogeneity index for the four study zones was 64.1 , which is fairly high. ${ }^{11}$

\footnotetext{
9 Unfortunately, language and ethnic group were not included in the criteria - a regrettable result of the cross-country comparative nature of the LLI Study.

10 If a household reported fewer than three important groups, the averaging procedure was done over whichever number of groups was actually reported.

11 For comparison, in Indonesia the equivalent score was 53.5 and for Burkina Faso it was 77.0.
} 
Table 18: Social Capital Dimensions, by Region and Household Characteristics

\begin{tabular}{|c|c|c|c|c|c|c|c|}
\hline & $\begin{array}{c}\text { Memberships } \\
\text { in Sindicatos } \\
\text { Campesinos } \\
(\%) \\
\end{array}$ & $\begin{array}{c}\text { Memberships } \\
\text { in Other Local } \\
\text { Associations } \\
\text { (number) } \\
\end{array}$ & $\begin{array}{c}\text { Index of } \\
\text { Heterogeneity }\end{array}$ & $\begin{array}{c}\text { Meeting } \\
\text { Attendance }\end{array}$ & $\begin{array}{c}\text { Index of } \\
\text { Participation } \\
\text { In Decision } \\
\text { Making } \\
\end{array}$ & $\begin{array}{c}\text { Index of } \\
\text { Contributions }\end{array}$ & $\begin{array}{l}\text { Community } \\
\text { Orientation }\end{array}$ \\
\hline \multicolumn{8}{|l|}{ Municipality } \\
\hline Charagua & 17.6 & 1.0 & 56.8 & 6.6 & 85.7 & 5.8 & 56.4 \\
\hline Mizque & 90.4 & 0.3 & 52.3 & 5.4 & 88.3 & 4.8 & 76.7 \\
\hline Tiahuanacu & 88.0 & 0.8 & 73.8 & 3.7 & 86.7 & 4.7 & 73.3 \\
\hline Villa Serrano & 57.2 & 0.9 & 72.7 & 5.4 & 77.7 & 1.7 & 64.5 \\
\hline \multicolumn{8}{|l|}{ Head of Household } \\
\hline Male & 63.3 & 0.8 & 64.0 & 5.3 & 85.2 & 4.4 & 67.6 \\
\hline Female & 63.1 & 0.6 & 64.1 & 4.7 & 82.8 & 3.3 & 74.7 \\
\hline \multicolumn{8}{|l|}{ Religion } \\
\hline Catholic & 64.0 & 0.7 & 63.2 & 5.0 & 84.2 & 4.2 & 70.3 \\
\hline Evangelical Protestant & 58.8 & 0.9 & 68.7 & 6.2 & 89.2 & 5.2 & 57.1 \\
\hline \multicolumn{8}{|l|}{ Education of Head } \\
\hline None & 71.7 & 0.5 & 66.9 & 4.4 & 84.2 & 2.9 & 73.5 \\
\hline Primary - Incomplete & 62.5 & 0.8 & 63.6 & 5.7 & 85.5 & 4.3 & 68.6 \\
\hline Primary - Completed & 62.8 & 0.9 & 61.3 & 5.1 & 84.3 & 5.3 & 67.0 \\
\hline Secondary — Incomplete & 60.0 & 0.9 & 59.7 & 5.5 & 83.9 & 5.1 & 66.8 \\
\hline Secondary - Completed & 53.1 & 0.9 & 70.3 & 4.7 & 86.7 & 3.8 & 61.1 \\
\hline Vocational & 40.0 & 1.5 & 74.5 & 3.8 & 86.0 & 6.2 & 52.2 \\
\hline University/Other & 22.2 & 1.6 & 72.0 & 2.9 & 81.3 & 3.2 & 58.3 \\
\hline \multicolumn{8}{|l|}{ Quintile } \\
\hline Poorest & 58.0 & 0.8 & 67.8 & 4.4 & 85.3 & 3.5 & 63.1 \\
\hline 2 & 62.5 & 0.9 & 62.7 & 5.5 & 86.0 & 3.0 & 61.0 \\
\hline 3 & 67.5 & 0.7 & 64.8 & 5.3 & 87.7 & 4.2 & 74.6 \\
\hline 4 & 66.5 & 0.7 & 62.4 & 5.5 & 85.5 & 5.1 & 71.2 \\
\hline Richest & 62.0 & 0.7 & 62.7 & 5.2 & 80.1 & 5.5 & 72.8 \\
\hline All & 63.3 & 0.8 & 64.1 & 5.2 & 84.9 & 4.3 & 68.5 \\
\hline \multicolumn{8}{|c|}{$\begin{array}{l}\text { Variable definitions are (for details, see text): } \\
\text { - Memberships in sindicatos campesinos: percent of households who are members of sindicatos campesinos. } \\
\text { - } \quad \text { Memberships in other local associations: average number of memberships per household. } \\
\text { - } \quad \text { Index of heterogeneity: scale }(0-100) \text { of internal heterogeneity of three most important groups, according to nine criteria. } \\
\text { - } \quad \text { Meeting attendance: average number of times a household member attended a group meeting in the last three months. } \\
\text { - Index of participation in decision making: scale }(0-100) \text { of extent of active participation in decision making in three most important groups. } \\
\text { - } \quad \text { Community orientation: percent of memberships in organizations which are community-initiated. }\end{array}$} \\
\hline
\end{tabular}


Table 19: Social Capital Dimensions, by Region and Quintiles

\begin{tabular}{|c|c|c|c|c|c|c|}
\hline \multirow{3}{*}{ Municipality } & \multicolumn{5}{|c|}{ Quintile } & \multirow[t]{2}{*}{ Total } \\
\hline & Poorest & 2 & 3 & 4 & Richest & \\
\hline & \multicolumn{6}{|c|}{ Memberships in Sindicatos Campesinos (\%) } \\
\hline Charagua & 17.3 & 24.6 & 15.7 & 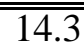 & 12.8 & 17.6 \\
\hline Mizque & 95.5 & 90.3 & 94.1 & 90.6 & 86.6 & 90.4 \\
\hline Tiahuanacu & 92.2 & 92.2 & 96.3 & 80.8 & 76.2 & 88.0 \\
\hline Villa Serrano & 52.0 & 64.2 & 61.4 & 57.1 & 51.7 & 57.2 \\
\hline Total & 58.0 & 62.5 & 67.5 & 66.5 & 62.0 & 63.3 \\
\hline \multicolumn{7}{|c|}{ Memberships in Other Local Associations } \\
\hline Charagua & 0.8 & 1.0 & 0.7 & 1.3 & 1.1 & 1.0 \\
\hline Mizque & 0.5 & 0.3 & 0.3 & 0.3 & 0.3 & 0.3 \\
\hline Tiahuanacu & 0.7 & 0.9 & 0.9 & 0.8 & 0.9 & 0.8 \\
\hline Villa Serrano & 0.9 & 1.1 & 1.1 & 0.8 & 0.8 & 0.9 \\
\hline Total & 0.8 & 0.9 & 0.7 & 0.7 & 0.7 & 0.8 \\
\hline \multicolumn{7}{|c|}{ Index of Heterogeneity } \\
\hline Charagua & 56.6 & 53.2 & 57.2 & 57.3 & 61.5 & 56.8 \\
\hline Mizque & 55.6 & 54.4 & 53.7 & 48.6 & 52.7 & 52.3 \\
\hline Tiahuanacu & 71.1 & 68.7 & 76.2 & 74.9 & 78.4 & 73.8 \\
\hline Villa Serrano & 76.9 & 72.5 & 69.7 & 71.2 & 69.4 & 72.7 \\
\hline Total & 67.8 & 62.7 & 64.8 & 62.4 & 62.7 & 64.1 \\
\hline \multicolumn{7}{|c|}{ Meeting Attendance } \\
\hline Charagua & 5.4 & 6.5 & 8.4 & 7.3 & 6.2 & 6.6 \\
\hline Mizque & 4.3 & 5.9 & 5.0 & 5.6 & 5.7 & 5.4 \\
\hline Tiahuanacu & 3.6 & 4.2 & 3.9 & 3.4 & 3.3 & 3.7 \\
\hline Villa Serrano & 4.4 & 5.6 & 5.3 & 6.8 & 5.5 & 5.4 \\
\hline Total & 4.4 & 5.5 & 5.3 & 5.5 & 5.2 & 5.2 \\
\hline \multicolumn{7}{|c|}{ Index of Participation in Decision making } \\
\hline Charagua & 91.5 & 92.1 & 91.1 & 81.5 & 69.3 & 85.7 \\
\hline Mizque & 94.7 & 87.5 & 93.2 & 88.5 & 83.5 & 88.3 \\
\hline Tiahuanacu & 88.5 & 86.3 & 86.0 & 89.3 & 82.9 & 86.7 \\
\hline Villa Serrano & 75.1 & 77.4 & 79.5 & 78.4 & 81.3 & 77.7 \\
\hline Total & 85.3 & 86.0 & 87.7 & 85.5 & 80.1 & 84.9 \\
\hline \multicolumn{7}{|c|}{ Index of Contribution } \\
\hline Charagua & 6.5 & 3.9 & 5.8 & 6.4 & 7.5 & 5.8 \\
\hline Mizque & 2.8 & 2.5 & 5.2 & 6.3 & 4.7 & 4.8 \\
\hline Tiahuanacu & 4.0 & 4.1 & 3.6 & 5.4 & 7.0 & 4.7 \\
\hline Villa Serrano & 1.4 & 1.0 & 2.4 & 1.8 & 2.6 & 1.7 \\
\hline Total & 3.5 & 3.0 & 4.2 & 5.1 & 5.5 & 4.3 \\
\hline \multicolumn{7}{|c|}{ Community Orientation } \\
\hline Charagua & 41.0 & 52.5 & 70.6 & 58.9 & 64.7 & 56.4 \\
\hline Mizque & 75.0 & 78.9 & 81.6 & 73.0 & 76.1 & 76.7 \\
\hline Tiahuanacu & 79.2 & 67.2 & 72.7 & 73.9 & 73.6 & 73.3 \\
\hline Villa Serrano & 59.7 & 52.5 & 71.1 & 73.8 & 74.0 & 64.5 \\
\hline Total & 63.1 & 61.0 & 74.6 & 71.2 & 72.8 & 68.5 \\
\hline
\end{tabular}


The index shows a distinct regional and socioeconomic pattern (Table 18). Associations in Tiahuanacu and Villa Serrano are much more heterogeneous than in the other two municipalities. The index follows a U-shaped pattern in relation to education: heterogeneity is highest for people with low or no education and for those with the highest amount of education. The index is not systematically related to income level, although households in the poorest quintile appear to be members of slightly more heterogeneous associations (Table 19). It is also worth noting that the internal heterogeneity of the agrarian syndicates and that of other associations do not systematically differ from each other (Table 20).

\section{(3) Meeting Attendance}

Meetings are often considered an indicator of participation. We therefore constructed a meeting attendance index which measured the average number of times someone from the household attended group meetings, normalized for the number of memberships of each household.

For each membership in an association, the average sample household attends 5.2 meetings in a three-month period. This figure is slightly higher in Charagua and lower in Tiahuanacu. Male heads of households attend meetings more frequently than female heads of households. Meeting attendance shows an inverse U-pattern with respect to education and level of income: the highest meeting attendance is recorded for people in the middle quintiles and with average levels of education. Meetings of agrarian syndicates are generally attended slightly less frequently than those of other organizations, except in Tiahuanacu (Table 20).

\section{(4) Active Participation Index}

It has been argued that associations which follow a democratic pattern of decision making are more effective than others. The LLI questionnaire asked association members to evaluate subjectively whether they were "very active", "somewhat active", or "not very active" in the group's decision making. This response was scaled from 2 to 0 respectively, and averaged across the three most important groups. The resulting index was re-scaled from 0 to 100 . The average value for this index is 84.9 , indicating a very high degree of active participation in decision making.

The index is systematically higher for agrarian syndicates than for other organizations. This explains why the index is the highest for Tiahuanacu and Mizque, the two municipalities where agrarian syndicates are most active. Male heads of households participate somewhat more actively than female heads of households. The correlation with education and income is weak except that the richest quintile shows a lower participation rate than others. However, as Table 19 indicates, there are strong regional differences in this correlation. In Charagua, active participation in the Guarani councils is at a very high level (over 90\%) for the lowest three quintiles and then declines sharply with income thereafter. In Villa Serrano, the reverse pattern is observed and active participation is the highest in the two richest quintiles. In Tiahuanacu and Mizque, the correlation with income is weaker. 
Table 20: Social Capital Dimensions, by Region and Type of Institution

\begin{tabular}{|c|c|c|}
\hline & $\begin{array}{c}\text { Sindicatos } \\
\text { Campesinos }\end{array}$ & $\begin{array}{l}\text { Other Local } \\
\text { Associations }\end{array}$ \\
\hline Municipality & \multicolumn{2}{|c|}{ Index of Heterogeneity } \\
\hline Charagua & 59.2 & 55.8 \\
\hline Mizque & 51.6 & 56.1 \\
\hline Tiahuanacu & 72.4 & 77.3 \\
\hline Villa Serrano & 71.9 & 71.9 \\
\hline Total & 63.8 & 65.7 \\
\hline \multicolumn{3}{|c|}{ Meeting Attendance } \\
\hline Charagua & 5.3 & 6.7 \\
\hline Mizque & 5.4 & 5.4 \\
\hline Tiahuanacu & 4.0 & 3.8 \\
\hline Villa Serrano & 5.2 & 5.8 \\
\hline Total & 4.9 & 5.5 \\
\hline \multicolumn{3}{|c|}{$\begin{array}{c}\text { Index of Participation in } \\
\text { Decision making }\end{array}$} \\
\hline Charagua & 89.8 & 85.1 \\
\hline Mizque & 90.0 & 83.7 \\
\hline Tiahuanacu & 89.0 & 83.6 \\
\hline Villa Serrano & 85.8 & 72.2 \\
\hline Total & 88.7 & 80.9 \\
\hline \multicolumn{3}{|c|}{ Index of Contribution } \\
\hline Charagua & 4.1 & 6.0 \\
\hline Mizque & 5.4 & 3.7 \\
\hline Tiahuanacu & 5.1 & 4.0 \\
\hline Villa Serrano & 1.2 & 1.9 \\
\hline Total & 4.2 & 4.1 \\
\hline \multicolumn{3}{|c|}{ Community Orientation } \\
\hline Charagua & 79.5 & 52.2 \\
\hline Mizque & 79.0 & 59.1 \\
\hline Tiahuanacu & 86.1 & 45.1 \\
\hline Villa Serrano & 93.7 & 37.9 \\
\hline Total & 84.8 & 47.2 \\
\hline
\end{tabular}

\section{(5) Membership Dues}

All other things being equal, it is presumably a sign of greater interest in the association if one is willing to pay membership dues. Only 20\% of associations in Bolivia charge such fees, which on average amount to Bs. 6.6 per year. However, almost two-thirds of memberships in associations require a labor contribution which on average amounts to 19 days per year. We constructed an index which averaged contributions in cash and in kind and whereby the highest contributed amount or number of days was set equal to 100 . The low value of the resulting index (4.3) reflects the high number of associations where no membership fees at all are charged. The index is highest in Charagua and lowest in Villa Serrano. The contributions required by agrarian syndicates on average do not differ from those required by other organizations (Table 20). 


\section{(6) Community Orientation}

Many case studies on the functioning of local associations have argued that voluntary organizations that find their roots in the community are more effective than externally imposed and/or mandated groups (Uphoff, 1992; Narayan, 1995; Ostrom, 1995). Eightyfive percent of respondents regarded the agrarian syndicates as being community initiated. As discussed earlier, this is a remarkable result given that historically the syndicates were established by the government as a vehicle for political control. It underscores the degree to which the nature of the organization and the local involvement have changed over time. Only $47 \%$ of other local organizations are community-initiated (Table 20). In Mizque and Charagua, however, there was a stronger degree of community involvement in setting up non-syndicate organizations. 


\section{Household Welfare and Social Capital}

In this section we address the question whether households with a higher level of social capital are better off. In other words, can we establish empirically a positive correlation between an index of social capital or the dimensions of social capital discussed in he previous section and various outcome indicators which measure household welfare? In principle it is not difficult to adjust a conventional model of household economic behavior to reflect the role of social capital. Such a model consists of three sets of equations.

- The first set of equations explains the income generating behavior of the household and describes how the household combines its various asset endowments to make decisions regarding labor supply for each of its members, taking the wage rates and demand situation in the labor market as given. In this formulation, social capital can be considered as one among several classes of assets available to the household to make its decisions. Social capital is combined with human capital, physical capital and the ownership of land to make productive decisions.

- The second set of equations portrays the household's demand for inputs (agricultural inputs, credit) and services (education, health) which may need to be combined with labor supply in order to ge nerate income. Here too, social capital is one category of capital which determines these decisions.

- A third set of equations explains the households' consumption and savings behavior as a function of the level and composition of income.

The customary reduced-form model of these structural equations relates household expenditure directly to the exogenous asset endowment of the household and yields the following estimating equation: ${ }^{12}$

$$
\ln \mathrm{E}_{i}=\alpha+\beta S C_{i}+\gamma H C_{i}+\delta O C_{i}+\varepsilon X_{i}+\eta Z_{i}+u_{i}
$$

Where $\quad \mathrm{E}_{i}=$ household expenditure per capita of household $\mathrm{i}$

$S C_{i}=$ household endowment of social capital

$H C_{i}=$ household endowment of human capital

$O C_{i}=$ household endowment of other assets

$\mathrm{X}_{i}=$ a vector of household characteristics

$\mathrm{Z}_{i}=\mathrm{a}$ vector of village/region characteristics

$u_{i}=$ error term

12 This reduced-form model was also the basis for the empirical study by Narayan and Pritchett (1997) on social capital in Tanzania. 
The key feature of this model is the assumption that social capital is truly "capital" and hence has a measurable return to the household. Social capital has many "capital" features: it requires resources (especially time) to be produced, and it is subject to accumulation and decumulation. ${ }^{13}$ Social capital can be acquired in formal or informal settings, just like human capital (e.g., schools versus learning-by-doing). Much social capital is built during interactions which occur for social, religious, or cultural reasons. Other interactions occur in settings specifically aimed to yield economic benefits. In Bolivia, this is the case with the agrarian syndicates and other production-oriented groups. The key assumption is that the networks built through these interactions have measurable benefits to the participating individuals, and lead, directly or indirectly, to a higher level of well-being. This is the proposition which we test empirically in this paper by means of equation (1). Structurally, the returns to social capital could be measured in the earnings functions if, e.g., one's network helps in getting better-paying jobs or promotions. It could also show up in the various functions that determine access to credit, agricultural inputs or other factors which enhance the productivity of a household enterprise.

The dependent variable of equation (1) is the natural logarithm of household expenditure per capita. ${ }^{14}$ The explanatory variables consist of the asset endowments of the households, demographic control variables, and locational dummy variables. Household assets are assumed to consist of human capital, social capital, land, and physical assets. We have already discussed in the previous section the variables used to measure the household's endowment of social capital. Human capital is measured conventionally by the years of education of the adult members of the household. ${ }^{15}$ Three productive assets relevant in rural settings were included: the number of hectares of land owned, the number of large animals and the number of pieces of major farm equipment.

In addition to the asset variables, the regressions include demographic variables, such as household size and gender of the head of household. Age of the head of household and its squared term were included to capture the life cycle of household welfare. Lastly, a set of dummy variables were included to indicate the municipality (Tiahuanacu was used as the omitted category) and whether households lived in the municipality's capital city. These variables capture the general economic and social conditions of the municipalities along dimensions other than those which we were able to include in the model.

The social capital dimensions which we discussed in the previous section can be included in the model as separate variables or they can be aggregated into an index. A study by Narayan and Pritchett (1997) which estimated the effect of social capital on the welfare of households in Tanzania used a multiplicative index capturing the number of

13 Events in transition economies such as Russia and former Yugoslavia are powerful evidence of the effects of the decumulation of social capital (Rose, 1995).

14 This variable was constructed in nominal form and does not capture any regional price variation that may exist in Bolivia. As of writing we do not have access to a regional price index to deflate household expenditure per capita. We assume that the regional dummy variable included in the regression will capture price differences.

15 The LLI questionnaire recorded only the level of educational achievement of each adult in the household and the number of years of education was imputed from that information. 
memberships in associations, their internal heterogeneity, and aspects of internal functioning. The use of a multiplicative procedure regards the different dimensions as interacting with one another, e.g., heterogeneity or internal functioning may have different effects depending upon the number of organizations of which the household is a member. However, it is also possible to consider an additive index whereby the assumption is made that each social capital dimension acts independently (although not necessarily with equal weight). The conceptual literature on social capital is not advanced to the stage that theoretical arguments can be put forth to select one model or the other. We show therefore in Table 21 the results of different aggregations as well as the model which includes the dimensions separately. In line with the index used by Narayan and Pritchett (1997), we constructed a multiplicative index of the number of memberships, the index of heterogeneity and the index of active participation in decision making. We also constructed an additive index as the arithmetic average of all six social capital dimensions. As an alternative, we constructed an additive index of four of the six social capital dimensions, excluding the heterogeneity index and the index of active participation (for reasons discussed below).

Column 1 of Table 21 indicates that the basic reduced-form model of household welfare, excluding any social capital variables, explains $41 \%$ of the variance in household welfare. Most of the included assets and control variables are significant. The results indicate that an additional year of education on average yields a $4.7 \%$ higher level of household welfare. The results indicate fairly low returns to the ownership of land and animals, but very high returns to the ownership of farm equipment (such equipment is owned by relatively few households). There is a distinct life-cycle pattern to welfare, peaking at age 58. Women-headed households, all other things being the same, have a $10 \%$ lower welfare level than male-headed households. The large and significant coefficients of the locational dummy variables indicate that there remain important location-specific determinants of household welfare which were not captured by the model.

Columns 2 and 3 show the results of adding respectively a multiplicative and an additive index of social capital to the specification. ${ }^{16}$ Of the two indexes only the additive specification has a coefficient significantly different from zero. The coefficient of the social capital index indicates that an increase of 10 points on the index is associated with a $5.7 \%$ increase in household welfare.

Column 3 indicates that an increase in the household's stock of human capital of one year is associated with an increase in household welfare of approximately $4.5 \%$. Among the sample households, the average stock of human capital equals four years so this corresponds to a $25 \%$ increase. A similar increase in the index of social capital (average $=23.6$ ) is associated with an increase of $3.4 \%$ of household welfare. This

16 Significance tests indicated that the additive index with four dimensions performed better than the one with six dimensions, hence only the results of the former are shown here. 
suggests that the returns to education are of similar magnitude to the returns of social capital. $^{17}$

The last column of Table 21 introduces the six social capital dimensions separately. This leads to a slight increase in the model's ability to explain the variance of household welfare relative to the index approach. More importantly, it shows the relative importance of the different dimensions. The results indicate that active membership in an agrarian syndicate is associated with an $11.5 \%$ higher level of household welfare. Membership in another association leads to a $5.3 \%$ increase in welfare. Active investments by households in associations - measured by attending meetings, making cash or in-kind contributions - as well as a strong community orientation are all associated with higher welfare levels, although the coefficients are fairly small. ${ }^{18}$

In the context of the model which we discussed in section 3 , the coefficient of membership is interpreted as the benefit of membership in local associations. It is possible, however, that there is reverse causation. High income households might have a higher demand for associational life because they have more leisure (although the opportunity cost to their time is also higher). One can certainly argue that associational life has a consumption value and is not sought merely for its economic benefit. Clearly this is related to the type of association: participating in a church choir or a soccer club may have more consumption value than the agrarian syndicate or other professional associations. We address later (section 8) formally the question of reverse causation with instrumental variables.

The results in Table 21 indicate that the heterogeneity index is not a significant social capital dimension, which is a different result from that obtained for Indonesia and Burkina Faso (Grootaert, 1999; Grootaert, Oh and Swamy, 1999). As has been noted in the previous section, the heterogeneity index in Bolivia is in-between that of the two other countries. However, also as noted before, neither heterogeneity in language nor ethnicity, both critical indicators, could be included in our heterogeneity index. As the qualitative data shows, ethnicity in the Bolivian context does matter. It appears that other demographic and socioeconomic characteristics are not important criteria for membership in associations and bear no relation to the effectiveness of the association. A noteworthy

17 Strictly speaking the coefficient of human capital cannot be interpreted as the returns to education because we do not employ the standard Mincerian formulation of the human capital model. The term "return" is used here to indicate the partial effect of a one unit increase in the stock of human or social capital on household welfare.

18 The regression model distinguishes membership in agrarian syndicates from other memberships because the organizations have different historical origins and because the extent of membership is very different. The variables describing the other social capital dimensions, however, do not make that distinction. As Table 20 indicated, there are no fundamental differences in social capital characteristics in terms of heterogeneity, meeting attendance, etc., between syndicates and other organizations. We did however estimate the regression model distinguishing between syndicates and other organizations for each of the six social capital dimensions. The empirical results indicated that among the syndicate characteristics, only membership was significant and that the other attributes of the syndicates did not have a significant impact on the outcome variables. We therefore distinguish in Table 22 and following tables syndicates and other associations only in the membership variable. 
result is the negative and significant coefficient of the index of participation. This result too stands in contrast to that obtained for the other two countries in the LLI study. Looking back at Tables 19 and 20 makes clear why this is the case: active participation in the decision making of associations is strongest among poorer households, especially in Mizque and Charagua. (Incidentally, the negative sign of the participation index and the lack of significance of the heterogeneity index explain why the additive model excluding these two components performs better than the index which consists of all six components and why the multiplicative index fails to be significant.)

\section{Table 21: Household Welfare and Social Capital (OLS regressions) ${ }^{1}$}

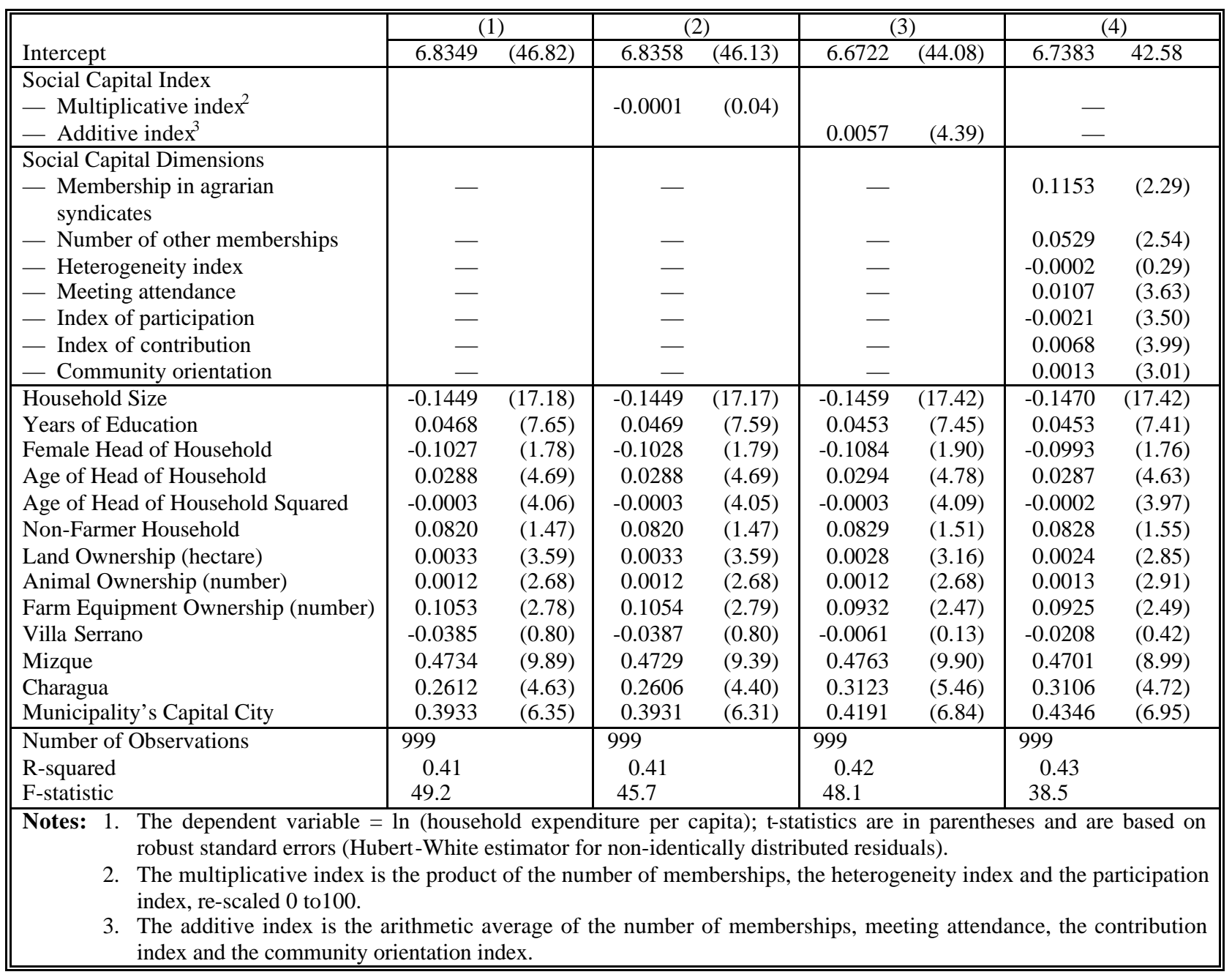

\section{Regional Differences}

Given the regional differences in ethnicity, geography, history and relative prosperity, reinforced by the high coefficients of the locational dummy variables, and to tease out the institutional story, we thought it would be worthwhile to estimate regressions separately for each municipality and for rural residents and those of the capital cities of the 
municipalities. Table 22 shows that the relative role of the different social capital dimensions is indeed different between rural and urban areas. Overall, the returns to social capital in local institutions appear to be higher in cities than in rural areas. While an active membership in an agrarian syndicate leads to a $9 \%$ higher level of household welfare in rural areas, in the cities this corresponds to an increase of $36 \%$. For other associations the respective figures are $4.5 \%$ and $17.5 \%$. These differences need to be interpreted with caution. The urban sample is small (only 100 households) and active membership in agrarian syndicates is low. The few urban residents who are farmers and members of agrarian syndicates are likely to be very different from the typical rural campesino.

Table 22: Household Welfare and Social Capital, by Location

\begin{tabular}{||l|rr|rr||}
\hline & \multicolumn{2}{|c|}{ Rural Areas } & \multicolumn{2}{c||}{$\begin{array}{c}\text { Municipality Capital } \\
\text { Cities }\end{array}$} \\
\hline Social Capital Index (additive) & 0.0055 & $(3.98)$ & 0.0077 & $(1.94)$ \\
\hline Social Capital Dimensions & & & & \\
— Membership in agrarian syndicates & 0.0906 & $(1.67)$ & 0.3611 & $(2.09)$ \\
— Number of other memberships & 0.0454 & $(2.08)$ & 0.1753 & $(2.04)$ \\
— Heterogeneity index & -0.0003 & $(0.34)$ & 0.0023 & $(0.88)$ \\
- Meeting attendance & 0.0110 & $(3.65)$ & -0.0162 & $(0.93)$ \\
- Index of participation & -0.0016 & $(2.46)$ & -0.0060 & $(3.15)$ \\
- Index of contribution & 0.0065 & $(3.67)$ & -0.0031 & $(0.37)$ \\
- Community orientation & 0.0012 & $(2.56)$ & 0.0020 & $(1.65)$ \\
\hline
\end{tabular}

We also re-estimated the regression model for each municipality separately as well as for combinations of municipalities along the institutional dimensions identified in Figure 1. Looking at the results for each municipality, the additive social capital index is only significant in Villa Serrano and Charagua (Table 23). These two provinces are characterized by a weak institutional tradition. In Villa Serrano the agrarian syndicates are not well established because the haciendas survived the 1952 revolution. In Charagua, the Assembly of the Guarani People has only been formally established since 1987 . However, as discussed earlier, this weak institutional tradition also explains why the incidence and membership of other local institutions is higher in Villa Serrano and in Charagua. Furthermore, since the agrarian syndicates are so weak, they lay little claim on the human resources available in the region which are therefore available to strengthen the functioning of other local organizations (Sandoval et al, 1998).

The results of the individual municipality regressions confirm the importance of non-syndicate organizations in Villa Serrano and Charagua since these are the only two provinces where there is a positive and significant relationship between membership in other local associations and household welfare level. However, the results also indicate that in none of the four municipalities, active membership in agrarian syndicates is significantly related to household welfare. The fact that we found such a significant relation at the national level means therefore that this is largely due to inter-municipality effects. In particular, Mizque is the province with the highest income as well as the highest active membership in agrarian syndicates. 
Table 23: Household Welfare and Social Capital, by Municipality

\begin{tabular}{|c|c|c|c|c|c|c|c|c|}
\hline \multirow[b]{2}{*}{ Social Capital Index (additive) } & \multicolumn{2}{|c|}{ Tiahuanacu } & \multicolumn{2}{|c|}{ Villa Serrano } & \multicolumn{2}{|c|}{ Charagua } & \multicolumn{2}{|c|}{ Mizque } \\
\hline & 0.0029 & $(0.90)$ & 0.0115 & $(4.78)$ & 0.0063 & $(2.94)$ & -0.0024 & $(0.87)$ \\
\hline \multicolumn{9}{|l|}{ Social Capital Dimensions } \\
\hline syndicates & -0.1244 & $(1.07)$ & 0.0877 & $(0.93)$ & 0.1095 & $(1.33)$ & 0.0960 & $(0.55)$ \\
\hline - Number of other memberships & 0.0277 & $(0.65)$ & 0.0756 & $(2.70)$ & 0.1097 & $(2.10)$ & 0.0101 & $(0.15)$ \\
\hline - Heterogeneity index & 0.0037 & $(1.73)$ & -0.0045 & $(3.55)$ & 0.0038 & $(2.40)$ & -0.0019 & $(0.92)$ \\
\hline - Meeting attendance & -0.0001 & $(0.01)$ & 0.0195 & $(3.76)$ & 0.0060 & $(1.86)$ & 0.0182 & $(2.64)$ \\
\hline — Index of participation & -0.0023 & $(1.45)$ & 0.0010 & $(0.84)$ & -0.0057 & $(5.31)$ & -0.0030 & $(2.05)$ \\
\hline — Index of contribution & 0.0124 & $(4.49)$ & 0.0150 & $(3.06)$ & 0.0027 & $(0.98)$ & 0.0035 & $(0.78)$ \\
\hline - Community orientation & 0.0010 & $(1.19)$ & 0.0029 & $(2.85)$ & 0.0023 & $(2.89)$ & -0.0005 & $(0.65)$ \\
\hline & \multicolumn{2}{|c|}{$\begin{array}{c}\text { Tiahuanacu and } \\
\text { Mizque } \\
\text { (strong } \\
\text { institutional } \\
\text { tradition) } \\
\end{array}$} & \multicolumn{2}{|c|}{$\begin{array}{l}\text { Villa Serrano and } \\
\text { Charagua } \\
\text { (weak institutional } \\
\text { tradition) }\end{array}$} & \multicolumn{2}{|c|}{$\begin{array}{c}\text { Mizque and } \\
\text { Charagua } \\
\text { (strong leadership } \\
\text { and municipal } \\
\text { effectiveness) }\end{array}$} & \multicolumn{2}{|c|}{$\begin{array}{l}\text { Tiahuanacu and } \\
\text { Villa Serrano } \\
\text { (weak leadership } \\
\text { and municipal } \\
\text { effectiveness) } \\
\end{array}$} \\
\hline Social Capital Index (additive) & 0.0014 & $(0.64)$ & 0.0081 & $(5.05)$ & 0.0032 & $(1.86)$ & 0.0083 & $(4.17)$ \\
\hline \multicolumn{9}{|l|}{$\begin{array}{l}\text { Social Capital Dimensions } \\
- \text { Membership in agrarian }\end{array}$} \\
\hline - Number of other memberships & -0.0033 & $(0.10)$ & 0.0758 & $(3.00)$ & 0.0826 & $(1.99)$ & 0.0486 & $(2.00)$ \\
\hline - Heterogeneity index & 0.0012 & $(0.88)$ & -0.0013 & $(1.28)$ & 0.0009 & $(0.77)$ & -0.0012 & $(1.15)$ \\
\hline - Meeting attendance & 0.0136 & (1.94) & 0.0094 & $(3.53)$ & 0.0107 & $(3.05)$ & 0.0119 & $(2.33)$ \\
\hline — Index of participation & -0.0025 & $(2.52)$ & -0.0021 & $(2.60)$ & -0.0037 & $(4.58)$ & -0.0002 & $(0.17)$ \\
\hline - Index of contribution & 0.0097 & $(4.40)$ & 0.0047 & $(1.76)$ & 0.0043 & (1.93) & 0.0111 & $(3.94)$ \\
\hline - Community orientation & 0.0001 & $(0.22)$ & 0.0023 & $(3.80)$ & 0.0007 & $(1.31)$ & 0.0019 & $(2.79)$ \\
\hline
\end{tabular}

The case of Mizque is of further interest. Mizque is the municipality where the agrarian syndicates are most effective and where they are the primary channel of delivery of various services to households. Active membership in the agrarian syndicates is almost universal and there is hence less need for other local institutions. The regression results for Mizque indicate that no single social capital dimension is significant except for meeting attendance. This result is puzzling because one could argue that in an environment where everyone is member, free riding could presumably be high. But Mizque is also a small area with high face to face interaction even in the town. In this environment, in a context of high membership, the ability of households to obtain benefits of this situation may depend on their presence at meetings. Mizque is also one of two municipalities where active participation in decision making is inversely related to income.

At the national level we found that there is no systematic relationship between the heterogeneity index and household welfare. The municipality results, however, indicate that heterogeneity is a significant dimension of associational life, but not everywhere in the same direction. In Tiahuanacu and Charagua, more heterogeneity is positively associated with higher income but in Villa Serrano and Mizque it is negatively related (although the relationship is statistically significant only in Villa Serrano). The reasons for these differences are not immediately clear and need to be explored further. The finding is probably related to the ethnic or linguistic composition of the population (which was not included in the index). Villa Serrano, where the relation is most pronouncedly negative, is largely populated by the Quechua indigenous groups, although that group is largely hispanicized and the majority of the population speaks Spanish. However, Spanish is also the predominant language in Charagua where the relationship between heterogeneity and 
income is strongly positive (note, however, that the population of Charagua is split about 50-50 between indigenous and other people). Mizque and Tiahuanacu are the most ethnically homogeneous municipalities with predominantly indigenous people, but the relation between heterogeneity and household welfare is not the same in the two municipalities.

We noted earlier the negative correlation between participation in decision making and household welfare, reflecting the fact that the poor participate more actively than the rich. This result is predominantly due to Mizque and Charagua, and in this regard the regressions confirm the earlier tabular results (see Table 19). The importance of community initiation of local associations is strongest in Villa Serrano and Charagua, which as we discussed earlier are the two municipalities with the weakest traditional institutions and hence the highest membership in non-syndicate local associations.

A fuller social capital story emerges when municipalities are paired according to the strength of traditional institutions, strength of regional leadership and linkage organizations and presence of effective municipal government, i.e., along the dimensions of Figure 1.

The regressions of pairs of municipalities suggest that all these institutional dimensions identified in Figure 1 are relevant in explaining the impact of local institutions on household welfare. Comparing Tiahuanacu and Mizque where institutional traditions are strong with Villa Serrano and Charagua where institutional traditions are weak, it is clear that in the latter context, the active membership of households in agrarian syndicates and other local associations explains variations in household welfare to a much stronger degree. Community initiation and involvement in the associations as indicated by meeting attendance and making large contributions are strong positive factors. In Tiahuanacu and Mizque in contrast, membership in local associations per se, regardless of type (i.e., whether they are syndicates or not, whether they are community or state initiated) does not matter, and differential effects on household welfare are due to differences in the degree of involvement by households in the affairs of the associations through meeting attendance and contributions.

Comparing Tiahuanacu and Villa Serrano where regional leadership and municipal effectiveness are weak with Mizque and Charagua where leadership and municipal government are strong, the results indicate that the latter situation contributes to a stronger positive correlation between membership in local associations and household welfare. This may reflect the complementarity between the actions of local associations and a municipal government which is responsive to local needs.

\section{Is Social Capital a Pro-poor Asset?}

So far we have provided evidence that several dimensions of social capital and particular combinations of institutions have positive effects on household welfare. However, since equation (1) imposes constant parameters over the entire distribution, the results do not say whether social capital helps the poor to the same degree as the rich and whether investment in social capital can help poor groups escape from poverty. In this context, it is important 
to note that the 'ownership' of social capital (as measured by membership in local associations and its different dimensions) is much more equally distributed than other types of assets (Table 24).

Table 24: Ownership of Assets, by Quintile of Household Expenditure per Capita

\begin{tabular}{||l|r|r|r|r|r|r||}
\hline \hline & \multicolumn{7}{|c||}{ Quintile } \\
\hline & Poorest & $\mathbf{2}$ & $\mathbf{3}$ & $\mathbf{4}$ & Richest & All \\
\hline Social Capital Index & & & & & & \\
- Multiplicative index & 19.7 & 20.1 & 20.2 & 18.2 & 16.2 & 18.9 \\
- Additive index & 21.4 & 22.7 & 24.1 & 24.7 & 25.0 & 23.6 \\
\hline Years of Education & 3.3 & 3.8 & 3.9 & 4.1 & 4.5 & 3.9 \\
Land Ownership (hectare) & 2.7 & 3.9 & 2.9 & 2.7 & 4.8 & 3.4 \\
Animal Ownership (number) & 19.1 & 16.6 & 19.9 & 19.4 & 22.4 & 19.5 \\
Farm Equipment Ownership & 0.5 & 0.4 & 0.5 & 0.5 & 0.5 & 0.5 \\
$\quad$ (number) & & & & & & \\
Household Durables & 1.7 & 1.9 & 2.2 & 2.4 & 3.0 & 2.2 \\
\hline
\end{tabular}

The poorest quintile of households has only 3.3 years of education against 4.5 years for the richest quintile. Land and household durables are distributed more unequally. In contrast, the additive social capital index is only slightly below average for the poorest quintile and the multiplicative index is even above average. The question remains whether this accumulation of social assets by the poor is rational, in the sense that it indeed helps them escape poverty or at least provides them with relatively higher returns than other assets.

We address this question in several ways. First, we estimated a probit model of the likelihood to be poor. ${ }^{19}$ The results indicate that social capital can significantly reduce the probability to be poor (Table 25). A household which is an active member of an agrarian syndicate has a 14\% lower probability to be poor than a similar household with no membership. Membership in another local organization reduces the probability to be poor by $2.8 \%$. This $5: 1$ ratio is much higher than the $2: 1$ ratio we found earlier between the coefficients measuring the impact on household welfare, indicating that there is a stronger correlation between active membership in an agrarian syndicate and poverty status than between membership and welfare level in general. This could either reflect a strong poverty reducing effect resulting from the activities of agrarian syndicates, but it could also reflect that the syndicates are not always open to the poor and exclude them from active membership.

19 The poverty line was set at two-thirds of median household expenditure per capita. 
Table 25: Social Capital and the Probability to be Poor (probit estimation)

\begin{tabular}{|c|c|c|}
\hline & \multicolumn{2}{|c|}{ Impact on the Probability to be Poor } \\
\hline & & \\
\hline - Membership in agrarian syndicates & -0.1405 & $(3.60)$ \\
\hline - Number of other memberships & -0.0284 & $(2.15)$ \\
\hline - Heterogeneity index & 0.0009 & $(1.76)$ \\
\hline - Meeting attendance & -0.0083 & $(2.83)$ \\
\hline — Index of participation & 0.0006 & $(1.54)$ \\
\hline — Index of contribution & -0.0021 & $(1.21)$ \\
\hline - Community orientation & -0.0002 & $(0.86)$ \\
\hline Household Size & 0.0500 & $(9.55)$ \\
\hline Years of Education & -0.0214 & $(4.46)$ \\
\hline Female Head of Household & 0.0955 & $(2.38)$ \\
\hline Age of Head of Household & -0.0125 & $(3.49)$ \\
\hline Age of Head of Household Squared & 0.0001 & $(3.47)$ \\
\hline Non-Farmer Household & -0.0358 & $(1.06)$ \\
\hline Land Ownership (hectare) & -0.0029 & $(1.23)$ \\
\hline Animal Ownership (number) & -0.0003 & $(0.85)$ \\
\hline Farm Equipment Ownership (number) & -0.0168 & $(0.66)$ \\
\hline Villa Serrano & 0.0389 & $(1.15)$ \\
\hline Mizque & -0.0943 & $(3.00)$ \\
\hline Charagua & -0.0882 & $(2.31)$ \\
\hline Municipality's Capital City & -0.1230 & $(3.57)$ \\
\hline Number of Observations & \multicolumn{2}{|c|}{999} \\
\hline Log Likelihood & \multicolumn{2}{|c|}{-372.5} \\
\hline Chi-squared & \multicolumn{2}{|c|}{137.05} \\
\hline Probability $>$ Chi-squared & \multicolumn{2}{|c|}{0.0000} \\
\hline
\end{tabular}

Quantile regressions are a further way to explore differences in the role of social capital between the poor and the rich. Quantile regressions estimate the regression line through given points on the distribution of the dependent variable (whilst an OLS regression line goes through the mean) and can assess whether certain explanatory variables are weaker or stronger in different parts of the distribution. However, the coefficients of quantile regressions are conditional upon the values of the explanatory variables, and hence coefficients from quantile regressions are nt comparable with those of OLS regressions. ${ }^{20}$

The results from quantile regressions (Table 26) confirm that the importance of social capital and its specific dimensions is not the same across the distribution. Looking at the additive index, it appears that the correlation between social capital and household welfare decreases as one moves to higher levels of the distribution. An active membership of an agrarian syndicate is most critical for people located between the $25^{\text {th }}$ percentile and

20 Specifically, the coefficients show the effect of a marginal change in an explanatory variable on the $\mathrm{x}^{\text {th }}$ conditional quantile of the dependent variable (Buchinsky, 1998). 
the median of the distribution. Given that the poor are practically excluded from memberships in two municipalities, this result makes sense. As a substitute however, membership of local organizations, are most critical for the people in the lowest $25 \%$ of the distribution. The importance of attending meetings is highest at the $25^{\text {th }}$ percentile and gradually declines after that. It is quite remarkable that the coefficient of index of contribution gradually declines as one moves up the distribution. This indicates that the payoff of a dollar's worth of membership fee or a day worked as in-kind contribution is highest for the poorest and declines after that. These results strongly underline the importance, not only of membership, but of active participation in the activities of the association.

Table 26: Social Capital and the Distribution of Household Welfare (quantile regressions)

\begin{tabular}{|c|c|c|c|c|c|}
\hline & \multicolumn{5}{|c|}{ Quantile of the Distribution of Household Welfare } \\
\hline & 10 & 25 & $\begin{array}{c}50 \\
\text { (median) }\end{array}$ & 75 & 90 \\
\hline Social Capital Index (additive) & $0.0059 *$ & $0.0052^{*}$ & $0.0055^{*}$ & $0.0055^{*}$ & $0.0044 *$ \\
\hline Social Capital Dimensions & & & & & \\
\hline — Membership in agrarian syndicates & 0.0366 & $0.1564^{*}$ & $0.1240 *$ & 0.0851 & 0.0209 \\
\hline - Number of other memberships & $0.0568 *$ & $0.0613 *$ & 0.0284 & 0.0431 & 0.0574 \\
\hline - Heterogeneity index & 0.0008 & $-0.0019 *$ & -0.0002 & 0.0015 & 0.0005 \\
\hline - Meeting attendance & $0.0080 *$ & $0.0123^{*}$ & $0.0097 *$ & $0.0076^{*}$ & 0.0071 \\
\hline — Index of participation & -0.0010 & $-0.0016^{*}$ & $-0.0023 *$ & $-0.0036 *$ & -0.0014 \\
\hline — Index of contribution & $0.0135 *$ & $0.0103 *$ & $0.0082 *$ & $0.0061 *$ & 0.0011 \\
\hline - Community orientation & 0.0008 & 0.0010 & $0.0015 *$ & $0.0014 *$ & 0.0009 \\
\hline Years of Education & $0.0467 *$ & $0.0444^{*}$ & $0.0512 *$ & $0.0376^{*}$ & $0.0424^{*}$ \\
\hline Land Ownership (hectares) & 0.0000 & $0.0030 *$ & $0.0022 *$ & 0.0010 & $0.0059 *$ \\
\hline Animal Ownership (number) & 0.0006 & $0.0022 *$ & $0.0020 *$ & $0.0017^{*}$ & $0.0010 *$ \\
\hline $\begin{array}{l}\text { Farmer Equipment Ownership } \\
\text { (number) }\end{array}$ & $0.1064 *$ & $0.1056^{*}$ & $0.0751 *$ & 0.0900 & 0.0516 \\
\hline $\begin{array}{ll}\text { Note: } & \text { Entries are coefficients or } \\
& \text { distribution of household ex } \\
& 90 \% \text { confidence level. }\end{array}$ & (1) & Sils & ugit & 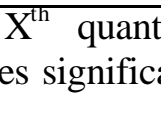 & he \\
\hline
\end{tabular}

A third way to assess whether the impact of social capital on household welfare varies across the distribution, is to split the sample according to households' endowment of assets. In the rural setting of the study area, land is clearly a key asset to households and we split the sample households according to whether they had less or more than one hectare of land (Table 27).

The results indicate that the correlation between social capital and household welfare is almost twice as strong for smallholders than for households with more land. The critical difference is in memberships in non-syndicate local organizations which are associated with an $8.3 \%$ increase in household welfare for smallholders against only $3.6 \%$ for households with more land. In contrast, the effect of active membership in an agrarian syndicate goes the other way. It is much higher for households with more than one hectare of land. 
Table 27: Social Capital and Land Ownership

\begin{tabular}{||l|c|l|c|c||}
\hline & \multicolumn{2}{|c|}{$<=1$ ha } & \multicolumn{2}{c||}{$>1$ ha } \\
\hline Social Capital Index (Additive) & 0.0071 & $(3.53)$ & 0.0039 & $(2.34)$ \\
\hline Social Capital Dimensions & & & & \\
- Membership in agrarian syndicates & 0.0858 & $(1.05)$ & 0.1364 & $(2.07)$ \\
- Number of other memberships & 0.0831 & $(2.16)$ & 0.0359 & $(1.46)$ \\
- Heterogeneity index & 0.0001 & $(0.01)$ & -0.0005 & $(0.47)$ \\
- Meeting attendance & 0.0193 & $(2.88)$ & 0.0059 & $(1.77)$ \\
- Index of participation & -0.0026 & $(2.95)$ & -0.0022 & $(2.75)$ \\
- Index of contribution & 0.0077 & $(4.28)$ & 0.0063 & $(1.99)$ \\
- Community orientation & 0.0014 & $(2.09)$ & 0.0010 & $(1.76)$ \\
\hline Entries are OLS coefficients and t-statistics based on robust standard errors. \\
\hline
\end{tabular}

In summary, the results of this section indicate that memberships in local associations contribute to higher household welfare and to reducing the probability to be poor. Returns to this social capital are generally higher for households in the lower half of the distribution and for smallholders. Which association matters most depends on the location, and is a function of the effectiveness of local government and the strength of institutional traditions. Where agrarian syndicates are weak, membership in other local associations tends to be strong, and vice versa. This relation of substitution and complementarity also occurs at the level of the household: the middle class and betterlanded households benefit more from agrarian syndicates, while the poor benefit most from other local institutions. 


\section{The Effects of Social Capital: Asset Accumulation, Access to Credit, Community Assistance, and Collective ACtion}

\section{Asset Accumulation}

So far we have concentrated on the impact of local associations on current income as proxied by expenditure per capita. However, in a relatively poor rural setting, a prime consideration for households is to have available coping strategies to deal with the risk of income fluctuations. Accumulating assets which can be sold or borrowed against in time of need or arranging access to credit are important components of such strategies. Households' ownership of consumer durable goods is one measure of the extent to which households have been able to save and accumulate assets. As we saw earlier (Table 6), the accumulation of household durables in the study areas is at a low level. Out of a list of 15 such assets, the average household owned only 2.2 assets.

We aggregated this information into a durable goods ownership score for the household using weights derived from a principal component analysis of the 15 variables. Re-estimating equation (1) with this ownership score as dependent variable provides an assessment whether social capital has contributed to asset accumulation and long-term increases in household welfare. The results (column 1, Table 28) indicate a strong correlation between membership in local organizations and ownership of durable goods. Active membership in an agrarian syndicate is associated with an increase in the ownership score of 0.076 (an increase of 12.1\%), while membership in other organizations is associated with an increase of 0.046 (an increase of $7.3 \%$ ). The results for the other dimensions are similar to those for current consumption, with the most important positive effect coming from meeting attendance. It is again noteworthy that the effect of human capital (years of education) is almost identical to that of social capital as measured by membership in organizations. The demographic and locational control variables in this equation show however very different results for the accumulation of durable goods as opposed to current expenditure. Specifically, female-headed households are at a much greater disadvantage, while non-farmer households have a much greater advantage in accumulating assets, controlling for all other characteristics. Among the locational variables, accumulation is much higher in cities than in rural areas although the differences between municipalities are smaller than was the case for current consumption.

Another aspect of asset accumulation is the ability to have savings. While the LLI questionnaire did not record the amount of savings, it did ask whether households had been able to increase savings in the past year. Households with more memberships in local associations were significantly more able to do so than others (column 2, Table 28). Membership in an agrarian syndicate was associated with a $4.8 \%$ higher probability of having increased savings, whilst the effect of membership in another association was associated with a $2.0 \%$ increase in this probability. We also tested whether membership in an association with specific financial objectives, for example, a rotating credit and savings association, made a difference. This did not turn out to be the case. The sample contained 
very few households with such memberships and none of them had been able to increase their savings in the past year.

Table 28: Social Capital and Asset Accumulation

\begin{tabular}{|c|c|c|c|c|}
\hline & \multicolumn{2}{|c|}{$\begin{array}{c}\text { Durable Goods } \\
\text { Ownership }^{1}\end{array}$} & \multicolumn{2}{|c|}{ Increasing Savings $^{2}$} \\
\hline Intercept & 0.0261 & $(0.22)$ & - & - \\
\hline \multicolumn{5}{|l|}{ Social Capital Diı } \\
\hline - Membership in agrarian syndicates & 0.0760 & $(1.75)$ & 0.0484 & $(1.84)$ \\
\hline - Number of other memberships & 0.0456 & $(2.62)$ & 0.0198 & $(2.04)$ \\
\hline - Heterogeneity index & -0.0005 & $(0.73)$ & 0.0004 & $(0.82)$ \\
\hline - Meeting attendance & 0.0048 & $(1.66)$ & 0.0040 & $(2.97)$ \\
\hline - Index of participation & -0.0011 & $(2.08)$ & -0.0008 & $(2.70)$ \\
\hline - Index of contribution & 0.0017 & $(0.83)$ & -0.0016 & $(1.53)$ \\
\hline - Community orientation & -0.0000 & $(0.00)$ & -0.0000 & $(0.03)$ \\
\hline Household Size & 0.0041 & $(0.68)$ & -0.0050 & $(1.29)$ \\
\hline Years of Education & 0.0454 & $(7.38)$ & 0.0150 & $(4.30)$ \\
\hline Female Head of Household & -0.1858 & $(4.32)$ & -0.0380 & $(1.42)$ \\
\hline Age of head of Household & 0.0134 & $(3.14)$ & -0.0038 & $(1.38)$ \\
\hline Age of Head of Household Squared & -0.0001 & $(2.73)$ & 0.0000 & $(1.06)$ \\
\hline Non-Farmer Household & 0.1669 & $(3.60)$ & 0.0330 & $(1.29)$ \\
\hline Land Ownership (hectare) & -0.0003 & $(0.37)$ & -0.0003 & $(0.64)$ \\
\hline Animal Ownership (number) & 0.0018 & $(2.98)$ & 0.0000 & $(0.10)$ \\
\hline Farm Equipment Ownership (number) & 0.1261 & $(3.86)$ & 0.0283 & $(1.72)$ \\
\hline Villa Serrano & -0.1978 & $(4.84)$ & 0.0434 & $(1.54)$ \\
\hline Mizque & -0.0038 & $(0.08)$ & 0.0331 & $(1.16)$ \\
\hline Charagua & -0.1741 & $(3.07)$ & 0.0427 & $(1.20)$ \\
\hline Municipality's Capital City & 0.5414 & $(8.05)$ & -0.0054 & $(0.19)$ \\
\hline Number of Observations & & & & \\
\hline R-squared & & & & \\
\hline F-statistic & & & & \\
\hline Log Likelihood & & & & \\
\hline Chi-squared & & & & \\
\hline $\operatorname{Pr}>$ chi-squared & & & & 000 \\
\hline \multicolumn{5}{|c|}{$\begin{array}{ll}\text { Notes: } 1 . & \text { OLS model with durable goods score (principal component weights) as dependent } \\
& \text { variable; reported are coefficients and t-values based on robust standard errors. } \\
\text { 2. } & \text { Probit model of households who increased savings in the past year; reported are } \\
& \text { probability derivatives at the mean of the explanatory variables (or for } 0 \text { to } 1 \text { change } \\
& \text { in the case of dummy variables) and z-scores based on robust standard errors. }\end{array}$} \\
\hline
\end{tabular}

\section{Access to Credit and Community Assistance}

Access to credit is still at a fairly low level in Bolivia and does not seem to be strongly related with the ability to provide collateral. Among households who owned one hectare or less of land, about $20 \%$ of households obtained credit in the past year. Among households with larger land holdings, $22 \%$ obtained credit. The analysis of access to credit in Indonesia and Burkina Faso indicated that local associations, regardless of whether the 
provision of financial services was the prime objective, played a key role in ensuring access to credit. The results of Table 29 suggest that this is not the case in Bolivia. Overall, the regression explaining the probability of obtaining credit showed only very low correlation with any of the social capital variables, as well as with most of the characteristics of the households. ${ }^{21}$ However, a noteworthy result is that larger and femaleheaded households are more likely to receive credit. Nevertheless, the key factor seems to be location. Specifically, being a resident of the municipality of Mizque provides a significant increase in the probability of obtaining credit. This municipality indeed has various local associations that specialize in this activity.

As we mentioned earlier, there are very few households in the sample who are members of an association with explicit financial objectives. However, the results in Table 29 do suggest that these associations achieved their objective since such membership is associated with a $22 \%$ increase in the probability to obtain credit.

In addition to inquiring about credit, the LLI questionnaire also asked households whether they thought they would be able to get assistance from people in the community other than relatives or friends in case of need. Sixty-four percent of households answered that they "definitely" or "probably" would be able to get such assistance. Among those, $22 \%$ listed community organizations as the first source where they would turn to for such help. Column 2 in Table 29 suggests that households who are members of local organizations are more likely to have faith in the community as a source of help. This is not at all related to the characteristics or the wealth of the household, but it is strongly influenced by the location. Households in Tiahuanacu are least likely to turn to the community for help, while those in Charagua are most likely to do so.

21 A Tobit regression explaining the amount of credit obtained yielded a similar result. 
Table 29: Social Capital and Access to Credit and Community Assistance

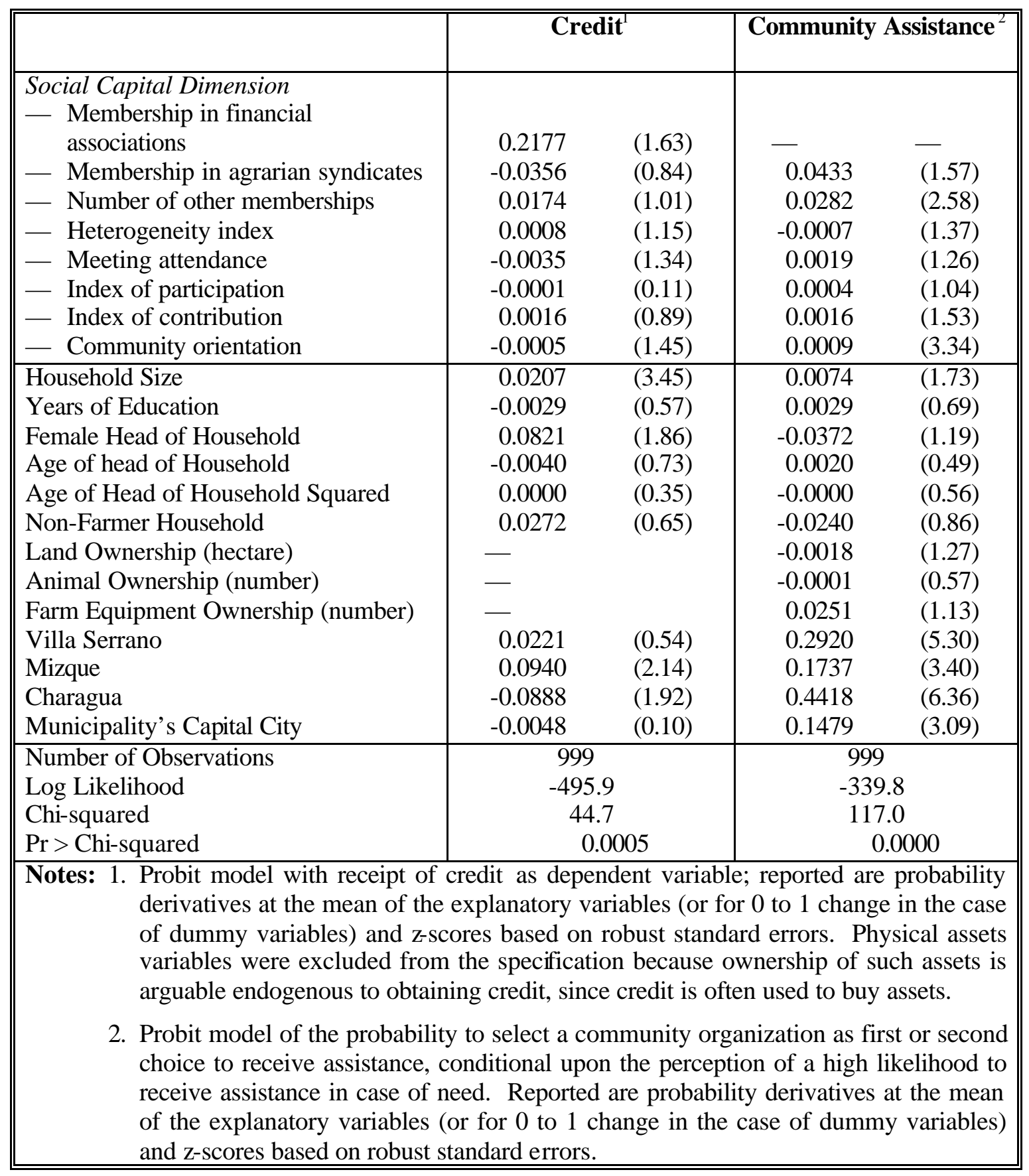

\section{Collective Action}

In addition to contributing to asset accumulation and to improving access to credit and assistance, social capital has also been documented to aid in collective action and collective decision making. This is especially relevant in rural settings where common property resources such as water, forestry or grazing land need to be managed by the 
community (Narayan, 1995; Uphoff, 1992). We regressed the number of times per year households participated in collective action against the social capital variables and the usual control variables (Table 30). On average, a Bolivian household participates 9 times per year in collective action. However, households who are active members of agrarian syndicates are likely to do this 11 times, while households who are members of other associations are likely to do this 10.4 times. This attests again to the "social" nature of social capital. Networks and interactions engaged in as part of social, religious, financial, or other objectives spill over in higher participation in activities that benefit the community at large.

Table 30: Social Capital and Collective Action

\begin{tabular}{|c|c|c|c|c|}
\hline & \multicolumn{2}{|c|}{ Household } & \multicolumn{2}{|c|}{ Village } \\
\hline Intercept & 11.3959 & $(2.72)$ & 32.4450 & $(0.56)$ \\
\hline \multicolumn{5}{|l|}{ Social Capital Dimensions } \\
\hline Membership in agrarian syndicates & 1.9328 & (1.16) & 13.5175 & $(1.81)$ \\
\hline Number of other memberships & 1.4479 & $(2.07)$ & 2.9119 & $(0.86)$ \\
\hline Heterogeneity index & -0.0472 & (1.89) & -0.0017 & $(0.01)$ \\
\hline Meeting attendance & 0.3255 & $(2.35)$ & 0.8657 & (1.47) \\
\hline Index of participation & 0.0106 & $(0.68)$ & -0.0608 & $(0.56)$ \\
\hline Index of contribution & 0.0886 & $(1.61)$ & 0.5676 & $(0.87)$ \\
\hline Community orientation & -0.0077 & $(0.76)$ & -0.1377 & $(1.57)$ \\
\hline Household Size & 0.0663 & $(0.35)$ & 0.1018 & $(0.05)$ \\
\hline Years of Education & 0.0570 & $(0.36)$ & -1.5303 & $(1.20)$ \\
\hline Female Head of Household & -2.4505 & $(1.83)$ & -19.4789 & (1.18) \\
\hline Age of Head of Household & 0.0224 & $(0.15)$ & -0.5183 & $(0.20)$ \\
\hline Age of Head of Household Squared & 0.0000 & $(0.01)$ & 0.0052 & $(0.18)$ \\
\hline Non-Farmer Household & -0.7780 & $(0.67)$ & 10.1704 & (1.73) \\
\hline Land Ownership (hectare) & -0.0190 & $(1.03)$ & 0.1271 & $(0.31)$ \\
\hline Animal Ownership (number) & -0.0221 & $(2.82)$ & -0.1290 & $(1.10)$ \\
\hline Farm Equipment Ownership (number) & 0.6830 & $(0.82)$ & -0.9767 & $(0.18)$ \\
\hline Villa Serrano & -6.3092 & $(4.05)$ & -8.8423 & (1.68) \\
\hline Mizque & -7.3358 & $(4.75)$ & -8.8985 & $(2.41)$ \\
\hline Charagua & -5.4669 & (3.10) & -4.5850 & $(0.91)$ \\
\hline Municipality’s Capital City & -5.7362 & $(4.44)$ & -2.1470 & $(0.49)$ \\
\hline Number of Observations & \multicolumn{2}{|c|}{974} & \multicolumn{2}{|c|}{40} \\
\hline R-squared & \multicolumn{2}{|c|}{0.10} & \multicolumn{2}{|c|}{0.69} \\
\hline F-statistic & \multicolumn{2}{|c|}{6.74} & \multicolumn{2}{|c|}{5.53} \\
\hline \multicolumn{5}{|c|}{$\begin{array}{l}\text { Notes: Dependent variable is the number of times a household participated in collective action } \\
\text { during the last year. Reported are OLS-coefficients and t-statistics based on robust } \\
\text { standard errors. }\end{array}$} \\
\hline
\end{tabular}

However, one result in Table 30 is distinctly different from what we found earlier. We have noted that in general the internal heterogeneity of local associations in Bolivia does not bear a strong relation to outcomes, whether current expenditure or asset accumulation or access to credit. In the case of collective action, however, the highest participation in collective action comes from members of internally more homogenous associations. This result was also found in the case of Indonesia (Grootaert, 1998) and 
points to a potential conflict between the interests of the households and those of the community. We have explored these results further to identify which of the nine dimensions that make up the heterogeneity index are most important in causing this result and it turns out that collective action is the highest in associations that are most homogenous according to kin, age, and education.

It is also worth noting that female-headed households are significantly less likely to participate in collective action than other households. There are also important locational effects. Collective action is more likely to take place in rural areas than in cities and it is most predominant in the municipality of Tiahuanacu.

Given that by nature collective action is organized at the level of the community, we also estimated the collective action regression using the village as unit of observation. The results largely confirm those of the household-level regression but they do highlight the role of agrarian syndicates: villages with high membership in the syndicates are significantly more likely to organize collective action.

\section{Household versus Village Effects}

Lastly, we wish to address to the question whether social capital operates primarily at the household level or at the village level. The earlier cited study on Tanzania by Narayan and Pritchett (1997) concluded that social capital is primarily a village effect, based on the significance of the social capital variables in village regressions. When we re-estimate equation (1) using the village as unit of observation, we find mixed results (results not reported here). ${ }^{22}$ The additive social capital index is significant in a village-level regression but the separate social capital dimensions are not. The sole, but important exception is the community orientation variable which is positively related to the welfare level of the village. These results suggest that in Bolivia social capital exhibits some village-level externalities, but that the distribution of benefits within the village is a function of the extent to which households are directly linked into the associational networks, via membership and active participation.

A further test of the relative role of village-effects versus household-effects consists of adding village-level social capital variables to the household regressions. We found that the household-level social capital variables retain their significance while the village-level social capital variables are not significant. This suggests that village-level social capital effects play little role in explaining the variance of household welfare (although they can of course explain the variance of village welfare).

This conclusion, however, needs to be treated with caution because of the possible existence of omitted-variable bias, in case the regression does not control for all relevant village factors. We try to tackle this question in two ways. As a first approach, we added to the basic specification of Table 21 a dummy variable for each village (minus one omitted village), under the assumption that these variables capture all omitted relevant

22 In a village-level regression, all variables are recalculated as village-level averages, with the exception of the location dummy variables. 
village factors. This raises the Rsquared from 0.42 to only 0.47 , suggesting that the amount of potential omitted variable bias is fairly limited. More importantly, it changes the coefficients of the social capital variables only very slightly and leaves their significance pattern unaffected. This suggests that our finding of significant social capital effects at the household level is not the result of omitted variables to capture the social capital effects at the village level.

A second and more interesting approach is to include in the regression information on the villages' general economic and social condition. The village-level data files include a number of economic variables (number of inhabitants, distance to nearest service center, presence of all-year passable road, number of development projects in the community), as well as a set of social and institutional variables. When added to equation (1), none turned out to be significant, lending strong support to the proposition that there is no omitted variable bias in the results discussed in this paper. 


\section{Social Capital and Household Welfare: Two-Way Causality?}

The model underlying this paper and presented in section 6 took the fundamental position that social capital is an input in the household's production function and can be modeled similar to human capital and other household asset endowments. However, like human capital, social capital is also, at least partly, a consumption good. This is certainly true for participation in non-mandatory social groups pursuing leisure activities. Since leisure is usually a luxury good, demand for it will rise with income, and then there could be a reverse causality from welfare level to social capital. If so, the estimated coefficient of social capital in equation (1) is upward biased.

The strongest evidence in support of a causation from social capital to income comes from estimating structural equations which indicate the role of social capital in access to services, such as credit or in determining collective action. Such evidence was presented by Narayan and Pritchett (1997) for Tanzania documenting the role of social capital in obtaining access to agricultural inputs such as fertilizer. Likewise, Grootaert (1998) documented the positive role of social capital in access to credit in Indonesia. Grootaert, Swamy and Oh (1998) similarly found that social capital was a powerful determinant in access to credit as well as in improving risk management for the household by reducing the forced sale of assets. In the case of Bolivia, the results presented in the previous section show weaker evidence of the role of social capital in providing access to credit although there is a strong role of social capital in collective action.

However, the extent of two-way causality is empirically testable by means of instrumental variable estimation. The real challenge is to find a suitable instrument set for social capital: instruments must determine social capital but not household welfare (nor be determined by household welfare). In order to make this task more feasible, we limit our attention to the model which uses a single social capital index. We argue that the following are conceptually suitable instruments for social capital:

(1) Ethnic and religious diversity of the village. This affects directly the potential heterogeneity of associations, which is one of the components of the aggregate social capital index. If there is only one religion in the village, it is not possible to have a religiously heterogeneous association. There is also no reason to assume that ethnic or religious composition would affect income, nor, obviously, will income affect diversity. ${ }^{23}$

(2) The density and democratic functioning of institutions in the village. Clearly, the possibility for a given household to join an association increases as more associations exist in the village. The likelihood to join and to be active in the association can also be expected to increase as institutions are perceived to function democratically. As we have already

23 This position is not inconsistent with the possibility that ethnic diversity may affect economic growth at the national level (as has been shown for Africa by Easterly and Levine, 1995, and Collier, 1998). 
demonstrated earlier, the density of associations at the village level does not significantly affect the level of household expenditure directly.

(3) The extent of community involvement in the creation of grassroots organizations. Where a community is perceived to be actively involved in the creation of local organizations, it may increase the level of trust in the association and hence make it more likely that households will join the association. This variable is the village equivalent of the community orientation variable which we used in the household regression. As our earlier results indicate, the village variable does not have a direct impact on the level of household expenditure.

Given the content of the available village data file, this leads to four possible instruments: an index of ethnic and religious diversity, the number of existing associations in the village, an index capturing whether leaders of the three most important associations are elected democratically, and an index capturing whether the three most important associations were originated by the community. ${ }^{24}$

We added those 4 variables to equation (1) and found that none were significant. Hence they meet the first criterion for being a valid instrument, namely not affecting household welfare. To test the second criterion, we applied the test for over-identifying restrictions proposed by Davidson and MacKinnon (1993). This tests the joint null hypothesis that the underlying model (equation (1) is correctly specified and that the applied instruments are valid. (The latter hypothesis cannot be tested separately.) Table 31 reports the test-statistic's p-value as well as the coefficient and t-statistic of the social capital index in the 2 SLS equation. To check for the sensitivity of results to specific instrument selection, we tested several combinations of the instruments. Although increases in the R-squared in the first stage equation are modest, all combinations of instruments pass the over-identifying restrictions test.

In all cases, the instrumental variables method leads to higher coefficients (ranging from 0.0153 to 0.0177 ) for the social capital index than in the OLS model (where it was 0.0057). This indicates that equation (1) is correctly specified and that social capital is an exogenous determinant of household welfare. If there were significant reverse causality, the coefficient of the social capital index in the 2SLS regression would have been lower than the OLS coefficient. This outcome is the same as that reported by Narayan and Pritchett (1997) for Tanzania, by Grootaert (1999) for Indonesia, and by Grootaert, Oh and Swamy (1999) for Burkina Faso.

The higher coefficient of the instrumented social capital index implies that a $10 \%$ increase in the household's social capital endowment leads to a $3.6 \%$ to $4.2 \%$ increase in household expenditure per capita. This is significantly larger than the effect from a $10 \%$

24 It is important to point out that these variables were collected independently of the household data, by means of interviews with village leaders, teachers, health professionals, etc., and also with focus groups of households who did not answer the household questionnaire. 
increase in the human capital endowment, which would increase household expenditure per capita by $1.6 \%$.

Table 31: Social Capital and Household Welfare: Instrumental Variables Results

\begin{tabular}{|c|c|c|c|c|}
\hline \multirow[b]{2}{*}{ Instrument Set } & \multicolumn{2}{|c|}{ Social Capital Index } & \multirow{2}{*}{$\begin{array}{c}\text { Incremental } \\
\text { R-squared }\end{array}$} & \multirow{2}{*}{$\begin{array}{l}\text { OIR Test } \\
\text { p-value }\end{array}$} \\
\hline & Coefficient & t-statistic & & \\
\hline $\begin{array}{l}\text { 1. Diversity, institutional density, } \\
\text { democratic functioning, } \\
\text { community initiation }\end{array}$ & 0.0177 & 2.18 & 0.024 & 0.97 \\
\hline $\begin{array}{l}\text { 2. Institutional density, democratic } \\
\text { functioning, community initiation }\end{array}$ & 0.0166 & 1.91 & 0.021 & 0.93 \\
\hline $\begin{array}{ll}\text { 3. Institutional density, community } \\
\text { initiation }\end{array}$ & 0.0153 & 1.62 & 0.018 & 0.87 \\
\hline
\end{tabular}

This finding strengthens the case for viewing social capital as an input in the household's production function. This in turn opens up the case for investing in social capital, just as investments are made in human capital. However, there is a critical difference: education is embodied in one individual and can be acquired by one individual regardless of what other people do. By definition, social capital can only be acquired by a group of people and requires a form of cooperation among them (although, as our results have shown, the extent to which different members of a group capture the benefits does depend upon their individual actions, especially the extent of active participation through meeting attendance and contributions). This gives social capital an inevitable public good character and this has implications for its production (Coleman, 1988, 1990). In particular, like all public goods, it will tend to be underproduced relative to the social optimum, unless the group responsible for its production can fully internalize the externality involved. Which group is best suited to producing social capital thus depends largely on the scope of the created externality and this determines the size of the group needed to internalize it effectively and avoid free rides. For example, in the case of farmers' associations, the scope is local; in the case of the rule of law, it is national and the central government needs to play the essential role.

However, the case of Bolivia also illustrates the importance of the linkages between the local associations and the municipal and regional government. The agrarian syndicates which were set up originally by the government have, over time, come to be perceived as community-oriented by many of the respondents in the study. In part this reflects the important role which these syndicates have played as a communication channel between the community and the local and regional level of government. Both functions — the creation of social capital among the members of the association and the linkage with other associations and with government - are the channels through which they benefit their members and the community. 


\section{SUMMARY AND CONCLUSION}

Bolivia is characterized by a large number and variety of local level institutions. We found 67 different types of local associations. On average, households belong to 1.4 groups and associations. The landscape of local institutions is dominated by the presence of agrarian syndicates which were created by government decree in 1952 but now are viewed primarily as community-initiated institutions to manage communal resources. As part of the Law of Popular Participation, these are territorial organizations that have been registered as legal entities to work closely with municipalities to represent the interests and priorities of local people in municipal decision making.

Of the total number of memberships, $45 \%$ were in agrarian syndicates, $12 \%$ in production groups, $9 \%$ in social service groups, and $7 \%$ in education and health groups with smaller numbers belonging to religious and government groups. Overall, $14 \%$ of the memberships were in NGO-initiated groups and another $8 \%$ in other supra-community groups. These included cross-community syndicate groups, trade and sports associations. In terms of gender, memberships in men-only groups were the most frequent $(43 \%)$, followed by memberships in mixed groups $(37 \%)$ and in women-only groups $(20 \%)$. The latter tended to be the most fequent in areas where NGOs had been active, particularly in Charagua and Villa Serrano.

The issue of the role of local level institutions was probed in different ways. Tabulation of which among the 67 groups households considered as the most important, revealed that agrarian syndicates ranked first, $41 \%$, followed by non-denominational NGOs, 14\%. Except for NGOs and religious groups, a majority of households said that the groups were initiated by the community and had formal status in the communities. There is still a strong communal orientation in the communities studied. When asked why households had joined the groups that they had rated the most important, approximately $50 \%$ said it was because of the positive impact on the community. Overall, $25 \%$ said that they had joined to improve household welfare. Households reported many benefits from belonging to groups. These included increased access to education services, water supply and sanitation, electricity, irrigation, agriculture technology, land and forest rights, credit and savings.

In many areas agrarian syndicates rotate leadership among households. While some writers consider this to be a drawback, this practice has led to the inclusion of the poor in leadership roles. Across the study sample, $51 \%$ of the poorest households reported having been in leadership positions in groups and associations. On the other hand, we did find evidence that suggests that in some areas the poor are excluded from active membership in the syndicates.

In addition to community-based groups, supra-community or linkage organizations that work across communities have important roles to play in linking groups and in collective bargaining. In this study, we found that $8 \%$ of memberships were in such organizations. Although numerically small, these organizations play critical roles in 
shifting basic power relations between community groups and the state, represented by the municipality.

There were important differences in the patterning of institutions in the four municipalities. In Mizque which has the highest per capita expenditure, almost everyone was an active member of agrarian syndicates. This was also true for Tiahuanacu with a $93 \%$ membership rate. By contrast, only $18 \%$ of households in Charagua and $48 \%$ of households in Villa Serrano were active in the syndicates. To substitute, in these two municipalities, households belong instead to a variety of production groups, social service and health and education groups. We found that the four municipalities could be distinguished along two dimensions: strength of traditional institutions on the one hand, and effective municipal government and supra-community leadership or linkage organizations, on the other hand. Mizque and Tiahuanacu have a strong institutional tradition, while Villa Serrano and Charagua have weak traditional institutions. We also found that Charagua and Mizque were characterized by strong regional leadership and effective municipal government while Tiahuanacu and Villa Serrano were characterized by ineffective municipal government and weak regional leadership. It is important to note that Mizque had the highest per capita expenditure and Villa Serrano the lowest per capita expenditure. This pattern is the result of the interaction of historical factors with the nature of society and long-term interventions by outside actors such as NGOs.

In this paper we estimated empirically the impact of social capital on household welfare and poverty in Bolivia. The focus was on households' memberships in local associations - an aspect of social capital that is particularly relevant for households' dayto-day decisions which affect their welfare and consumption.

We used a reduced-form model of household welfare, which controls for relevant household and location characteristics, to estimate the contribution of social capital to household welfare. The underlying structural equations treat social capital as an input, together with human and physical capital, in the household's production function. The effects of social capital operate through (at least) three mechanisms: sharing of information among association members, reduction of opportunistic behavior, and improved collective decision making. The magnitude of the social capital effect was found to be about 2.5 times larger than that of human capital. Increasing the average endowments of education for each adult in the household by one year (which is about a $25 \%$ increase) would increase household expenditure per capita by $4.2 \%$. A similar increase in social capital endowment would increase household expenditure per capita by $9 \%$ to $10.5 \%$.

We measured social capital along six dimensions: density of memberships, internal heterogeneity of associations (by gender, age, education, religion, etc.), meeting attendance, active participation in decision making, payment of dues (in cash and in kind), and community orientation. Among these, the strongest effect was found to come from the number of memberships. An active membership in an agrarian syndicate is associated on average with an $11.5 \%$ higher household expenditure per capita. A membership in another local association is associated with a 5.3\% higher expenditure level. However, our results also suggest that households who participate actively in the association by attending 
meetings frequently and by making larger contributions in cash or in kind benefit more than others. We also found that households who are primarily members of communityinitiated organizations obtain larger benefits, but this effect was quite small. A distinct feature of associational life in Bolivia is that the poor household groups participate more actively in decision making. This was especially observed in Mizque and Charagua.

The four study zones in our data set have a different institutional tradition as well as different strengths of regional leadership and municipal government. We found these features to be related to the impact of social capital at the household level. Specifically, in Mizque where membership in agrarian syndicates is almost universal, the impact of other local associations on household welfare is very small. In order to benefit, households need to participate actively in the associations by attending their meetings. Mizque also has strong linkage organizations, social cohesion and a strong municipal government. In Villa Serrano and Charagua, where the institutional tradition is weaker, we found a strong impact of membership both in agrarian syndicates and other associations on household welfare. Over and above this, active participation in the association and community initiation were found to be important variables. In Charagua, the linkage organizations are strong as is the municipal government, and the traditional organizational structures are being revived through the Guarani Assembly which has already become a political force in some areas.

Social capital reduces the probability to be poor, and the returns to household investment in social capital are generally higher for the poor than for the rich. The effect of the aggregate social capital index was about one-third larger at the $10^{\text {th }}$ percentile of the distribution than at the $90^{\text {th }}$ percentile. This was primarily due to membership in agrarian syndicates which had the largest impact between the $25^{\text {th }}$ percentile and the median of the distribution, while the impact of membership in other local organizations was the strongest in the bottom quartile of the distribution. Likewise, the benefits from membership are higher for households with little land than for those with more land. The poorest households in Bolivia are actually members of more non-syndicate organizations than the rich and our results indicate that this investment is warranted. It exceeds the returns to education and other assets quite significantly.

Social capital is hypothesized to have several long-term benefits, such as better access to credit and a resulting better ability to smoothen out income fluctuations by borrowing and/or accumulating assets. Our empirical results partially confirm the validity of these propositions. Households with higher levels of social capital are significantly more successful in accumulating household durables which suggests that they have been better able to smoothen out their consumption over time. Our results also provide direct evidence that these households have the highest probability of increasing their savings. On the other hand, we found only weak evidence that households which are well integrated in the network of local associations have better access to credit. We found the latter to be primarily a function of location, with access to credit being strongest in Mizque. We also found that households with many memberships in local associations and who frequently attend their meetings are more likely to participate in collective action. Households with strong ties in local associations also have a higher level of trust in their community as a source of assistance in case of need. 
Social capital affects household welfare but there can also be reverse causality: richer households could have a higher demand for memberships in associations and have more time to participate (although the opportunity cost of their time is also higher). Instrumental variable estimation suggested that the direct effect of social capital on welfare dominates the reverse effect in explaining the correlation between the two variables. This finding is robust for several sets of instruments available in the data.

Historical evidence also strengthens this interpretation. Agrarian syndicates were created almost 50 years ago in a situation of widespread poverty. Although this was accompanied by land reform, indigenous people did not get clear title over their land as did the elite. In areas where the haciendas were not broken up, other groups and organizations evolved to help people cope with inequitable distribution of assets and limited economic and social opportunity.

Thus, on balance, this study for Bolivia found compelling empirical evidence that local social capital - defined as household membership in local associations - makes a significant contribution to household welfare, over and above that stemming from human capital and other household assets.

\section{Policy Implications}

Our findings support a policy by governments, non-government organizations and donors to invest in social capital - either directly or indirectly by creating an environment friendly to the emergence of local associations. Our findings also indicate that investments in local social capital deserve to be part of poverty alleviation programs since the returns to investment in social capital are larger for the poor than for others.

However, policy prescriptions to support social capital formation of the type that reduces poverty in the context of social polarization have to be nuanced and take into account the local social relations and power structures both in informal and formal organizations. Not all institutions are equally inclusive or serve the needs of the poor. Institutions are embedded in history, culture and politics. All of these need to be understood to avoid the simplistic prescription of 'create local groups'. The creation of local associations in the context of Bolivia's ongoing decentralization process also requires a balanced approach to capacity building of both local government and local associations. There is a danger to overloading task and programs on communities before they have honed their skills to work effectively in municipal decision making. This is in fact already happening and will be counter-productive.

Given the radical changes in governance, democracy and laws supporting grassroots involvement in municipal government, we offer five specific recommendations for the Bolivian context.

First, the delivery of basic local infrastructure and basic health and education services should take into account the social structure and social inequities in designing of strategies to create participatory groups and associations. Processes that build inclusive social capital (i.e., including the poor and both men and women) at the local level in the 
delivery of these services will increase the degree of organization of local communities as well as increase the sustainability of these services. Funds to support these social and institutional processes need to be an integral part of project financing in exactly the same way as financing of physical construction.

Second, the country-wide processes of local participation and municipal decentralization need to be fine-tuned in recognition of the fact that they depend on local level social capital. In this context, the Bolivian government needs to monitor the social composition of vigilance committees and the density, composition and strength of both solidarity groups and supra-community linkage groups in local communities. Given the dangers of cooption of the vigilance committees by political parties, this monitoring will help refine municipal procedures and perhaps even election procedures. It is also important that data be gender disaggregated. Several writers have noted that territorial organizations tend to be dominated by men. In fact, even at the municipal level, as rural councils were given resources, the number of women councilors declined as more men became interested in what was perceived to be potentially powerful positions.

Third, as is already being done, technical assistance needs to be provided to grassroots organizations and vigilance committees and people need to be educated about the new laws and their rights. Technical assistance is also needed at the municipal level. Given the scale of the program, NGOs and other external support agencies have a role to play in technical assistance, both as links to outside resources and in the training of local organizations to fulfil their mandates without being coopted by the state. However, NGOs may have their own agenda, which may or may not be best suited for local empowerment strategies. Cross-linking or supra-community NGOs that stay in the region for a long time have important roles to play. As is now being done in other countries, local organizations should be able to choose their partners from among NGOs where they exist and buy needed technical assistance as part of grant programs funded through various channels.

Fourth, to transform the social capital of the poor from a coping strategy to a productive strategy will require investments in increasing poor people's access to productive assets, economic opportunity, education and credit.

Fifth, although groups and associations can be counted, the processes used in these groups, including rotation of leadership, leads to the acquisition of new skills and behaviors and new social connections. The social learning that takes place is probably as important as the direct benefits received by members. It is this social characteristic of groups that makes social capital different from other forms of capital. 
ANNEX: Means AND STANDARd DEVIATION OF REgRESSION VARIAbLES

\begin{tabular}{|c|c|c|c|c|c|c|c|c|c|c|}
\hline & \multicolumn{2}{|c|}{ Total } & \multicolumn{2}{|c|}{ Tiahuanacu } & \multicolumn{2}{|c|}{ "Villa Serrano } & \multicolumn{2}{|c|}{ Mizque } & \multicolumn{2}{|c|}{ "Charagua } \\
\hline & Mean & $\begin{array}{c}\text { Standard } \\
\text { Deviation }\end{array}$ & Mean & $\begin{array}{c}\text { Standard } \\
\text { Deviation }\end{array}$ & Mean & $\begin{array}{c}\text { Standard } \\
\text { Deviation }\end{array}$ & Mean & $\begin{array}{c}\text { Standard } \\
\text { Deviation }\end{array}$ & Mean & $\begin{array}{c}\text { Standard } \\
\text { Deviation }\end{array}$ \\
\hline Log (household expenditure per capita) & 7.33 & 0.65 & 7.30 & 0.60 & 7.11 & 0.63 & 7.61 & 0.63 & 7.29 & 0.64 \\
\hline Asset Ownership Score & 0.63 & 0.50 & 0.74 & 0.49 & 0.52 & 0.48 & 0.68 & 0.54 & 0.57 & 0.47 \\
\hline Proportion of Poor Households & 0.18 & 0.38 & 0.16 & 0.37 & 0.28 & 0.45 & 0.08 & 0.27 & 0.19 & 0.37 \\
\hline Collective Action & 8.87 & 13.48 & 13.27 & 19.54 & 7.15 & 10.97 & 6.94 & 8.28 & 8.16 & 11.56 \\
\hline Increased Savings & 0.09 & 0.29 & 0.08 & 0.27 & 0.12 & 0.32 & 0.09 & 0.28 & 0.10 & 0.30 \\
\hline Obtained Credit & 0.21 & 0.41 & 0.19 & 0.39 & 0.24 & 0.43 & 0.28 & 0.45 & 0.16 & 0.36 \\
\hline Community Assistance & 0.14 & 0.35 & 0.02 & 0.14 & 0.16 & 0.37 & 0.11 & 0.32 & 0.27 & 0.45 \\
\hline Social Capital Index & & & & & & & & & & \\
\hline Multiplicative index & 18.89 & 17.32 & 26.46 & 22.07 & 21.36 & 18.65 & 15.00 & 10.44 & 12.75 & 11.96 \\
\hline Additive index & 23.56 & 12.91 & 27.61 & 8.95 & 21.60 & 13.31 & 26.85 & 11.38 & 18.17 & 14.90 \\
\hline Social Capital Dimensions & & & & & & & & & & \\
\hline Membership in agrarian syndicates & 0.63 & 0.48 & 0.88 & 0.33 & 0.57 & 0.50 & 0.90 & 0.30 & 0.18 & 0.38 \\
\hline Number of other memberships & 0.77 & 0.91 & 0.84 & 0.90 & 0.95 & 1.09 & 0.33 & 0.63 & 0.95 & 0.83 \\
\hline Heterogeneity index & 56.50 & 27.34 & 73.46 & 16.05 & 59.33 & 32.52 & 50.04 & 18.65 & 43.16 & 28.61 \\
\hline Meeting attendance & 4.58 & 5.12 & 3.68 & 2.85 & 4.45 & 4.56 & 5.21 & 4.32 & 5.00 & 7.49 \\
\hline Index of participation & 74.84 & 35.68 & 86.37 & 22.54 & 63.43 & 38.70 & 84.43 & 28.16 & 65.13 & 43.12 \\
\hline Index of contribution & 3.77 & 7.62 & 4.71 & 7.96 & 1.38 & 3.58 & 4.56 & 6.95 & 4.42 & 10.05 \\
\hline Community orientation & 60.45 & 43.44 & 72.97 & 35.87 & 52.88 & 43.16 & 73.30 & 40.82 & 42.63 & 45.36 \\
\hline Household Size & 4.98 & 2.35 & 4.15 & 2.34 & 4.93 & 2.07 & 4.82 & 2.01 & 6.02 & 2.54 \\
\hline Years of Education & 3.90 & 2.81 & 3.57 & 3.15 & 3.33 & 2.50 & 3.67 & 2.57 & 5.04 & 2.66 \\
\hline Female Head of Household & 0.13 & 0.34 & 0.22 & 0.42 & 0.08 & 0.27 & 0.12 & 0.33 & 0.09 & 0.29 \\
\hline Age of Head of Household & 45.97 & 15.03 & 52.17 & 16.55 & 44.42 & 12.64 & 43.37 & 14.87 & 43.94 & 14.12 \\
\hline Age of Head of Household Squared & 2339.0 & 1530.6 & 2994.2 & 1829.9 & 2131.8 & 1174.6 & 2101.0 & 1478.9 & 2128.9 & 1381.6 \\
\hline Non-Farmer Household & 0.16 & 0.36 & 0.16 & 0.37 & 0.12 & 0.32 & 0.11 & 0.32 & 0.24 & 0.43 \\
\hline Land Ownership (hectare) & 3.41 & 11.15 & 3.46 & 3.92 & 3.43 & 7.33 & 2.08 & 2.62 & 4.66 & 20.47 \\
\hline Animal Ownership (number) & 19.47 & 31.36 & 21.17 & 15.68 & 17.84 & 24.52 & 16.05 & 31.16 & 22.81 & 45.81 \\
\hline Farm Equipment Ownership (number) & 0.46 & 0.53 & 0.80 & 0.42 & 0.52 & 0.51 & 0.46 & 0.55 & 0.04 & 0.30 \\
\hline Tiahuanacu & 0.25 & 0.43 & 1.00 & 0.00 & 0.00 & 0.00 & 0.00 & 0.00 & 0.00 & 0.00 \\
\hline Villa Serrano & 0.25 & 0.43 & 0.00 & 0.00 & 1.00 & 0.00 & 0.00 & 0.00 & 0.00 & 0.00 \\
\hline Mizque & 0.25 & 0.43 & 0.00 & 0.00 & 0.00 & 0.00 & 1.00 & 0.00 & 0.00 & 0.00 \\
\hline Charagua & 0.25 & 0.43 & 0.00 & 0.00 & 0.00 & 0.00 & 0.00 & 0.00 & 1.00 & 0.00 \\
\hline Municipality's Capital City & 0.10 & 0.30 & 0.10 & 0.30 & 0.10 & 0.30 & 0.10 & 0.30 & 0.10 & 0.30 \\
\hline Castellano & 0.40 & 0.49 & 0.06 & 0.23 & 0.96 & 0.21 & 0.02 & 0.14 & 0.58 & 0.49 \\
\hline Aymara & 0.24 & 0.42 & 0.94 & 0.23 & 0.00 & 0.00 & 0.00 & 0.00 & 0.00 & 0.00 \\
\hline Quechua & 0.26 & 0.44 & 0.00 & 0.00 & 0.04 & 0.21 & 0.98 & 0.14 & 0.00 & 0.00 \\
\hline Guarani & 0.11 & 0.31 & 0.00 & 0.00 & 0.00 & 0.00 & 0.00 & 0.00 & 0.42 & 0.49 \\
\hline Village Proportion - Non-Castellano & 0.60 & 0.41 & 0.94 & 0.09 & 0.04 & 0.10 & 0.98 & 0.05 & 0.42 & 0.22 \\
\hline
\end{tabular}




\section{REFERENCES}

Albó, X. 1994. "Ethnic Violence: The Case of Bolivia." in The Culture of Violence, Tokyo; New York: United Nations University Press.

Albó, X., 1995. "And from Kataristas to MNRistas? The surprising and bold alliance between Aymaras and Neoliberals in Bolivia." in Donna Lee Van-Cott (ed.), Indigenous Peoples and Democracy in Latin America, St. Martin's Press in association with the Inter-American Dialogue.

Albro, R. 1998. "Introduction: a New Time and Place for Bolivian Popular Politics." Ethnology, 37/2 (Spring '98) p. 99-115.

Bebbington, A. 1998. "Sustaining the Andes? Social Capital and Policies for Rural Regeneration in Bolivia." Mountain Research and Development, 18/2, pp. 173-181.

Birdsall, N., C. Graham, and R. H. Sabot (eds.). 1998. Beyond Tradeoffs: Market Reforms and Equitable Growth in Latin America. Washington, D.C.: Inter-American Development Bank; Brookings Institution Press.

Birdsall, Nancy and Juan Luis Londoño. 1997. "Asset Inequality Matters: An Assessment of the World Bank's Approach to Poverty Reduction." American Economic Review, 87/2, pp. 32-37.

Booth, D., S. Clisby and C. Widmark. 1996. Popular Participation and Rural Democratisation in Bolivia: Phase 1 report, Phase 2 report. (first draft), Department of Social Anthropology, Stockholm University.

Calderon, F. and J. Dandler (eds.). 1984. Bolivia: la fuerza histórica del campesinado, UNRISD, CERES, Cochabamba.

Coleman, J. 1988. "Social Capital in the Creation of Human Capital." American Journal of Sociology. 94 (Supplement) S95-S120.

Coleman, J. 1990. Foundations of Social Theory. Cambridge, Mass.: Harvard University Press.

Collier, P. 1998. "The Political Economy of Ethnicity." Paper presented at Annual Bank Conference on Development Economics, April 2-21, 1998. Washington, DC: World Bank.

Dasgupta, P. 1988. "Trust as a Commodity." In Gambetta, ed., Trust: Making and Breaking Cooperative Relations. Oxford: Blackwell.

Davidson, R. and J. MacKinnon. 1993. Estimation and Inference in Econometrics. New York: Oxford University Press. 
Easterly, W. and R. Levine. 1995. "Africa's Growth Tragedy: A Retrospective 1960-89". Policy Research Working Paper No. 1503. Washington, DC: World Bank.

Evans, P. 1996. "Government Action, Social Capital and Development: Reviewing the Evidence on Synergy." World Development, 24(6), pp.1119-1132

Faguet, Jean Paul. 1998. Decentralisation and Local Government Performance. Improving Public service provision in Bolivia. (mimeo), Centre for Economic Performance and Development Studies Institute, London: London School of Economics,

Garcia Arganaras, F. 1992. "Bolivia's Transformist Revolution." Latin American Perspectives, vol. 19 (Spring '92) pp. 44-71.

Graham, C. 1998. Private Markets for Public Goods: Raising the Stakes in Economic Reform. Washington, D.C.: Brookings Institution Press, 380 p.

Grootaert, Christiaan. 1998. Social Capital, Household Welfare and Poverty in Indonesia, Local Level Institutions Study. (draft), Social Development Department, Environmentally and Socially Sustainable Development Network. Washington, DC: World Bank.

Grootaert, Christiaan, Anand Swamy and Gi-Taik Oh. 1999. "Social Capital and Development Outcomes in Burkina Faso." Mimeo, Social Development Department. Washington, DC: World Bank.

Hartmann, Felipe. 1997/98. Land Reform and Social Capital, Their Roles in Social and Economic Development: A Case Study of Rural Bolivia. MSc Dissertation, LSE: Development Studies Institute.

Healy, K. 1996. "Ethnodevelopment of Indigenous Bolivian Communities: Emerging Paradigms." in Alan Kolata (ed.), Tiwanaku and its Hinterland: Archaeology and Paleoecology of an Andean Civilization, Washington; London: Smithsonian Institution Press. xix, 323 p.

Moe, J. A. 1997. Bolivia's Laws on Popular Participation and Administrative Decentralization: Progress and Challenges. (draft) Washington, DC: Inter-American Development Bank.

Narayan, D. 1995. "Designing Community-Based Development," Environment Department Paper No. 7, Washington, DC: World Bank.

Narayan, D. 1999. "Bonds and Bridges: Social Capital and Poverty." Policy Research Working Paper No. 2167, Washington, DC: World Bank.

Narayan, D. and L. Pritchett. 1997. "Cents and Sociability - Household Income and Social Capital in Rural Tanzania." Policy Research Working Paper No. 1796, Washington, DC: World Bank. 
O’Neill, K. and G. Malina. 1998. "Social Capital in a Multi-Ethnic Society", paper presented at the Annual Meeting of the American Political Science Association, Boston, Mass., September 3-6, 1998.

Ostrom, E. 1995. "Incentives, Rules of the Game, and Development." In M. Bruno and B. Pleskovic, eds., Annual Bank Conference on Development Economics 1995. Washington, DC: World Bank.

Pearse, A. 1984. "Campesinado y revolución: el caso de Bolivia", in Calderon and Dandler (1984).

Portes, A., and P, Landolt. 1996. "The Downside of Social Capital." The American Prospect. 26 (May-June): 18-21, 94.

Putnam, R. 1995. "Bowling Alone: America's Declining Social Capital.” Journal of Democracy, 6(1).

Putnam, R. with R. Leonardi and R. Nanetti. 1993. Making Democracy Work: Civic Tradition in Modern Italy. Princeton: Princeton University Press.

Rose, R. 1995. "Russia as an Hour-Glass Society: A Constitution without Citizens." East European Constitutional Review, 4(3).

Sandoval, G., J. Cordova, B. Ascarrunz, A. Balbóa, G. Gonzales and G. Velasques. 1998. "Grassroots Organizations and Local Development in Bolivia", Local Level Institutions Working Paper Number 4, Washington, DC: World Bank.

Ströbele-Gregor, J. 1994. "From Indio to Mestizo ... to Indio: New Indianist Movements in Bolivia." Latin American Perspectives, 21/2 (Spring '94) pp. 106-123.

Ströbele-Gregor, J. 1996. "Culture and political practice of the Aymara and Quechua in Bolivia: autonomous forms of modernity in the Andes." Latin American Perspectives, vol. 23 (Spring '96) pp. 72-90.

Tarrow, S. 1998. Power in Movement: Social Movements and Contentious Politics. Second Edition. Cambridge: Cambridge University Press.

Tilly, C. 1998. Durable Inequality. Berkeley: University of California Press.

Tuchschneider, David. 1998. Decentralization and Rural Development in Bolivia: In Search of a Model. (mimeo).

Uphoff, N. 1992. Learning from Gal Oya - Possibilities for Participatory Development and Post-Newtonian Social Science. Ithaca: Cornell University Press.

Woolcock, M. 1998. "Social Capital and Economic Development: Toward a Theoretical Synthesis and Policy Framework.” Theory and Society, 27(2), pp. 151-208. 
World Bank. 1996. Bolivia, Poverty, Equity, and Income: Selected Policies for Expanding Earning Opportunities for the Poor, Vol. 1. No. 15272-BO, LAC, Washington, DC: World Bank.

World Bank. 1998. "The Local Level Institutions Study: Program Description and Prototype Questionnaires." Local Level Institutions Working Paper No. 2, Social Development Department, Washington, DC: World Bank.

World Bank. 1999. World Development Report - Knowledge for Development, New York: Oxford University Press. 